\title{
Linking Climate Change and Groundwater
}

\author{
Timothy Richard Green
}

\begin{abstract}
Projected global change includes groundwater systems, which are linked with changes in climate over space and time. Consequently, global change affects key aspects of subsurface hydrology (including soil water, deeper vadose zone water, and unconfined and confined aquifer waters), surface-groundwater interactions, and water quality. Research and publications addressing projected climate effects on subsurface water are catching up with surface water studies. Even so, technological advances, new insights and understanding are needed regarding terrestrial-subsurface systems, biophysical process interactions, and feedbacks to atmospheric processes. Importantly, groundwater resources need to be assessed in the context of atmospheric $\mathrm{CO}_{2}$ enrichment, warming trends and associated changes in intensities and frequencies of wet and dry periods, even though projections in space and time are uncertain. Potential feedbacks of groundwater on the global climate system are largely unknown, but may be stronger than previously assumed. Groundwater has been depleted in many regions, but management of subsurface storage remains an important option to meet the combined demands of agriculture, industry (particularly the energy sector), municipal and domestic water supply, and ecosystems. In many regions, groundwater is central to the water-food-energy-climate nexus. Strategic adaptation to global change must include flexible, integrated groundwater management over many decades. Adaptation itself must be adaptive over time. Further research is needed to improve our understanding of climate and groundwater interactions and to guide integrated groundwater management.
\end{abstract}

T.R. Green $(\square)$

USDA, Agricultural Research Service (ARS), Fort Collins, Colorado, USA

e-mail:Tim.green@ars.usda.gov 


\subsection{Introduction and Motivation}

Present understanding of how global change affects water resources around the world is limited. Potential impacts of global change on surface water, particularly projected regional climate patterns and trends have been studied in some detail. Studies of how subsurface waters will respond to climate change coupled with human activities have started to catch up only recently (Green et al. 2011; Taylor et al. 2013).

Challenges of understanding climate-change effects on groundwater are unique, because climate change may affect hydrogeological processes and groundwater resources directly and indirectly, in ways that have not been explored sufficiently (Dettinger and Earman 2007). Data limitations have made it impossible to determine the magnitude and direction of groundwater change due solely to climate change (Kundzewicz et al. 2007; Taylor et al. 2013). Even so, groundwater has been an historical buffer against climate variability, and our dependence on groundwater resources is likely to increase as water supplies are further stressed by population increase and projected increases in temperature and climatic variability over much of the globe.

Observational data and climate predictions provide abundant evidence that freshwater resources (both surface and subsurface water resources) are vulnerable and have the potential to be strongly affected by climate change, with wide-ranging consequences for society and ecosystems (Bates et al. 2008). According to Jorgensen and Yasin al-Tikiriti (2003) the effect of historical climate change on groundwater resources, which once supported irrigation and economic development in parts of the Middle East, is likely the primary cause of declining cultures there during the Stone Age. Climate change may account for approximately $20 \%$ of projected increases in water scarcity globally (Sophocleous 2004). Integrated groundwater management and planning into the future requires careful evaluation and understanding of climatic variability over periods of decades to centuries, while considering the increasing stresses on those groundwater resources from population growth and industrial, agricultural, and ecological needs (Warner 2007).

\subsubsection{Rising Interest in Impacts of Climate Change on Subsurface Water}

In recent decades, a wide array of scientific research has been conducted to explore how water resources might respond to global change. However, research has been focused dominantly on surface-water systems, due to their visibility, accessibility and more obvious recognition of surface waters being affected by global change. Only recently are water resources managers and politicians recognising the important role played by groundwater resources in meeting the demands for drinking water, agricultural and industrial activities, and sustaining ecosystems, as well as in the adaptation to and mitigation of the impacts of climate change and coupled human activities. 
Changes in global climate are expected to affect the hydrological cycle, altering surface-water levels and groundwater recharge to aquifers with various other associated impacts on natural ecosystems and human activities. Although the most noticeable impacts of climate change could be changes in surface-water levels and quality (Leith and Whitfield 1998; Winter 1983), there are potential effects on the quantity and quality of groundwater (Bear and Cheng 1999; Zektser and Loaiciga 1993).

\subsubsection{What Is Global Change?}

Global change may include natural and anthropogenic influences on terrestrial climate and the hydrologic cycle. Greenhouse gases are assumed to drive much of the contemporary climate change, and global atmospheric $\mathrm{CO}_{2}$ concentration is the primary indicator of greenhouse gases, as well as a primary regulator of global climate (Petit et al. 1999). Atmospheric $\mathrm{CO}_{2}$ concentration has been measured in the middle of the Pacific Ocean atop Mauna Loa, Hawaii at the National Centre for Environmental Prediction since 1958 (Keeling et al. 1976; Keeling et al. 2004; Thoning et al. 1989). Both $\mathrm{CO}_{2}$ concentration and its rate of change have increased continuously over most of our lifetimes. Green et al. (2011) showed a power-law increase in $\mathrm{CO}_{2}$ concentration with time, but projections of future greenhouse gas concentrations are based on complex "storylines" (IPCC 2007b) or Representative Concentration Pathways (RCPs) used in the Fifth Assessment Report (AR5) (IPCC 2013). Projected climate change is based primarily on simulated responses to these projected emissions and resulting greenhouse gases.

Atmospheric scientists are exploring complex interactions and causative factors using available data and climate models. Ice-core data have shown long-term correlation between entrapped atmospheric $\mathrm{CO}_{2}$ and (surrogate) temperature (Petit et al. 1999); however, $\mathrm{CO}_{2}$ changes lag behind temperature changes by approximately 1,300 years (Mudelsee 2001). The Earth's orbit and "Milankovitch cycles" seem to explain the apparent paradox, possibly working in tandem with global greenhouse warming and ocean circulation (Monnin et al. 2001). Loáiciga (2009) provided a helpful discussion of several factors in the debate over dominant drivers of climate as it relates to (ground)water resources. These types of issues in the theory and prediction of climate have not been fully resolved.

Although "global warming" is the topic of greatest public interest, changing patterns of surface level air humidity and precipitation are very important for predicting eco-hydrological impacts of multifaceted climate change. Projections from the Intergovernmental Panel on Climate Change (IPCC) show significant global warming and alterations in frequency and amount of precipitation in the twenty-first century (Le Treut et al. 2007; Mearns et al. 2007). 


\subsection{Climate Projections}

Aquifers are recharged mainly by precipitation or through interaction with surfacewater bodies. In order to quantify potential effects of climate change on groundwater systems, future projections of climate are needed at the scales of application.

\subsubsection{Global Climate Models}

Climate models come in different forms, ranging from simple energy-balance models to Earth-system models of intermediate complexity to comprehensive three-dimensional general circulation models of the atmosphere and oceans or global climate models (GCMs). GCMs are the most sophisticated tools available for simulation of the current global climate and future climate scenario projections. Over the last few decades, physical processes incorporated into these models have increased from simple rain and $\mathrm{CO}_{2}$ emissions to complex biogeochemical (including water vapor) feedbacks (Le Treut et al. 2007: Fig. 1.2). The dominant terrestrial processes that affect large-scale climate over the next few decades are included in current climate models. Some processes important on longer time scales (e.g., global glaciation), however, are not yet included. The spatial resolution of GCMs has improved, but the simulation of extreme precipitation is dependent on model resolution, parameterisation and the thresholds chosen. In general, GCMs tend to produce too many days with weak precipitation $\left(<10 \mathrm{~mm} \mathrm{~d}^{-1}\right)$ and too little precipitation during intense events $\left(>10 \mathrm{~mm} \mathrm{~d}^{-1}\right.$ ) (Randall et al. 2007).

Considerable advances in model design have not reduced the variability of model forecasts of climate, partially because climate predictions are intrinsically affected by uncertainty and deterministic chaos (Lorenz 1963). Lorenz (1975) defined two distinct kinds of prediction problems: (1) prediction of actual properties of the climate system in response to a given initial state due to non-linearity and instability of the governing equations, and (2) determination of responses of the climate system to changes in the external forcings. Estimating future climate scenarios as a function of the concentration of atmospheric greenhouse gases is a typical example of predictions of the second kind (Le Treut et al. 2007).

Uncertainties in climate predictions arise mainly from model uncertainties and errors. A number of comprehensive model intercomparison projects were set up in the 1990s under the auspices of the World Climate Research Programme to undertake controlled conditions for model evaluation (e.g., Taylor 2001). Use of multiple simulations from a single model (ensemble or Monte Carlo approach) is a necessary and complementary approach to assess the stochastic and chaotic behaviors of the climate system. Such single-model ensemble simulations clearly indicated a large spread in the climate projections (Le Treut et al. 2007).

The ability of any particular GCM to reproduce present-day mean climate and its historical characteristics with respectable realism and good overall performance in comparison with the other models are presumed to indicate that it can be used to project credible future climates IPCC (2007b). The atmosphere-ocean coupled 
climate system shows different modes of variability that range widely from intraseasonal to inter-decadal time scales. Successful simulation and prediction over a wide range of these phenomena increase confidence in the GCMs used for climate predictions of the future (Randall et al. 2007). In addition, the IPCC (2007a) showed that the global statistics of the extreme events in the current climate, especially temperature, are generally simulated well. However, GCMs have been more successful in simulating temperature extremes than precipitation extremes (Randall et al. 2007).

Uncertainty is expected with respect to what the future "picture" of global climate will be. GCMs are forced with concentrations of greenhouse gases and other constituents derived from various emissions scenarios ranging from non-mitigation scenarios to idealised long-term scenarios. The IPCC (2007b) considered six scenarios for projected climate change in the twenty-first century. These included a subset of three IPCC Special Report on Emission Scenarios (SRES; Nakićenović and Swart 2000) non-mitigation emission scenarios representing 'low' (B1), 'medium' (A1B) and 'high' (B1) scenarios. Green et al. (2011) discussed some potential spatial patterns of these scenarios across the globe. These include different projected changes in precipitation for the tropics (Neelin et al. 2006), subtropics (Wang 2005; Rowell and Jones 2006), and high latitudes (Emori and Brown 2005).

\subsubsection{Downscaling}

GCMs cannot provide information at scales finer than their computational grid (typically of the order of $200 \times 200 \mathrm{~km}$ ), yet processes at smaller unresolved scales are important. Thus, the usefulness of the raw output from a GCM for climate change assessment in specific regions is limited. To bridge the spatial resolution gaps for GCMs to produce realistic local climate projections, downscaling techniques are usually applied to the GCM output.

Downscaling addresses the disparity between the coarse spatial scales of GCMs and observations from local meteorological stations (Hewitson and Crane 2006; Wilby and Wigley 1997). GCMs do not accurately predict local climate, but the internal consistency of these physically-based climate models provides most-likely estimates of ratios and differences (scaling factors) from historical (base case) to predicted scenarios (Loaiciga et al. 1996) for climatic variables, such as precipitation and temperature.

Improvements to climate projections will likely come by developing regional climate models and GCMs that couple groundwater and atmospheric processes (Cohen et al. 2006; Gutowski et al. 2002). The primary challenge is the difference in scale between the large (continental) scale of GCMs and the local scale of groundwater or surface-water models, requiring daily data and spatial resolution of a few square kilometers (Bouraoui et al. 1999; Loaiciga et al. 1996).

A clearer picture of the robust aspects of regional climate change is emerging due to improvement in model resolution, the simulation of processes of importance 
for regional change, and the expanding set of available simulations (Christensen et al. 2007). Downscaling techniques are grouped into two main types: (1) dynamic climate modelling, and (2) empirical statistical downscaling.

A number of different approaches have been used to derive climate data series for hydrogeological studies. The complexity of approaches for obtaining the climate data series appears to have increased in recent years, ranging from the use of global averages (Loaiciga et al. 1996; Zektser and Loaiciga 1993) to the use of regional "bulk" projections (Allen et al. 2004; Brouyere et al. 2004; Vaccaro 1992; Yusoff et al. 2002) to the direct application of downscaled climate data (Jyrkama and Sykes 2007; Scibek and Allen 2006b; Scibek et al. 2007; Serrat-Capdevila et al. 2007; Toews and Allen 2009) to the use of regional climate models (Rivard et al. 2008; van Roosmalen et al. 2007, 2009). Some of the early efforts to assess potential hydrologic impacts were reviewed by Gleik (1986). Most of these hydrologic models used daily weather series generated stochastically, with climate change shifts applied for future climate scenarios. Many studies have considered a range of GCMs or the average projection from several GCMs, and a few studies have considered different downscaling methods.

Green et al. (2011) discussed dynamic and statistical downscaling as alternatives for applying GCM results at the local scales of interest. Downscaled daily temperature generally compares well with observed data, but daily precipitation amounts often do not, particularly seasonal amounts and durations of wet and dry periods. Such discrepancies are important because of the highly nonlinear responses and sensitivities of dynamic vegetation growth and water use (transpiration) to precipitation regimes (Green et al. 2007). Allen et al. (2010) used state-of-the-art downscaling methods to predict variations in recharge. They found that the variability in recharge predictions indicates that the seasonal performance of the downscaling tool is important, and that a range of GCMs should be considered for water management planning. Yang et al. (2005) noted that sufficient potential evaporation (PE) data are rarely available to identify long term trends. Thus, they made use of limited daily data to study sub-weekly structure, and used this information to downscale weekly sequences. In this way the dual objectives of downscaling weekly data and simulating daily PE sequences could both be achieved.

\subsection{An Holistic View of Groundwater Hydrology: Selected Studies}

This section summarizes the current state of research and understanding of climatechange effects on subsurface hydrology and surface-subsurface hydrologic interactions. Climate change, including anthropogenic-global warming and natural climate variability, can affect the quantity and quality of various components in the global hydrologic cycle in the space, time, and frequency domains (Holman 2006; IPCC 2007b; Loaiciga et al. 1996; Milly et al. 2005; Sharif and Singh 1999). 


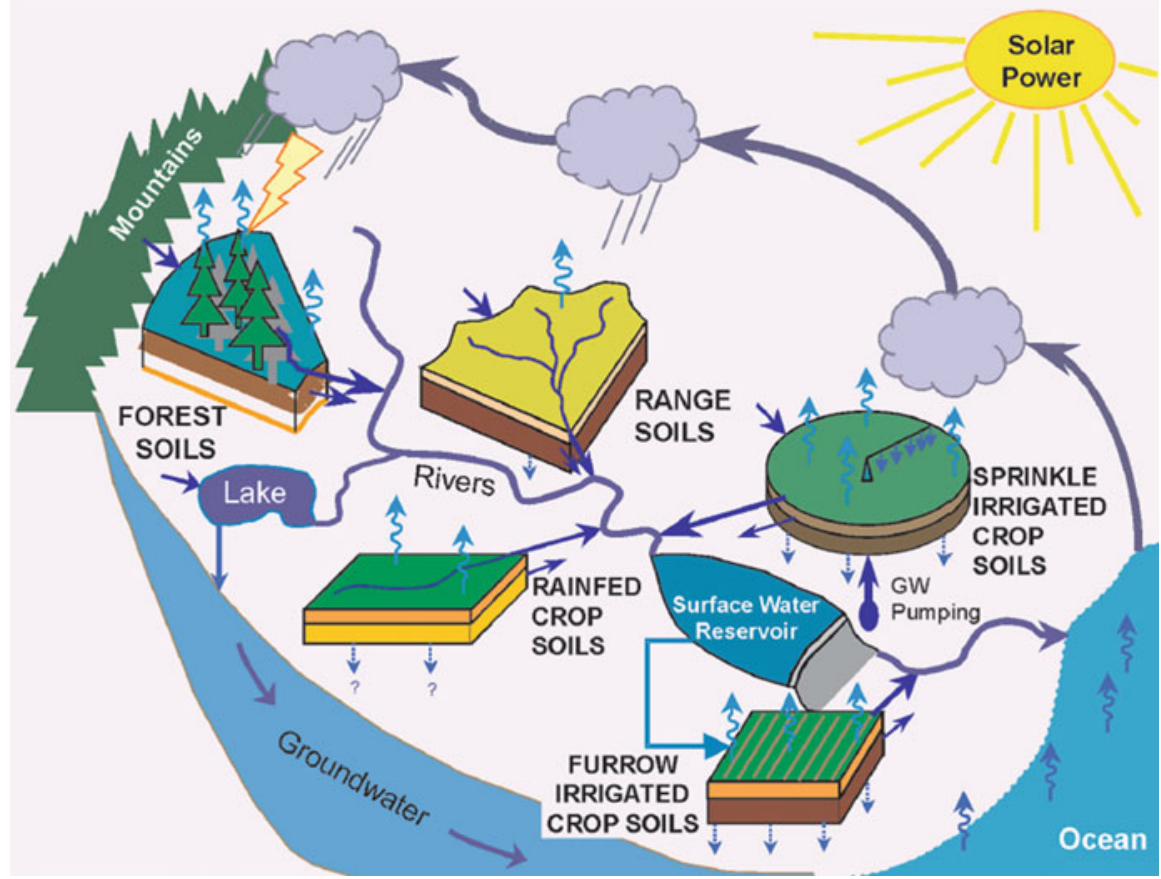

Fig. 5.1 Schematic illustration of the hydrologic cycle, including rainfed and irrigated agriculture with potential groundwater abstraction (Taken from Green and van Schilfgaarde 2006)

The components of the surface hydrologic cycle (Fig. 5.1) affected by climate change include atmospheric water vapor content, precipitation and evapotranspiration patterns, snow cover and melting of ice and glaciers, soil water content (SWC) and temperature, and surface runoff and stream flow (Bates et al. 2008). Such changes to the atmospheric and surface components of the global hydrologic cycle will likely result in changes to the subsurface hydrologic cycle within the soil, vadose zone, and aquifers of the world (Van Dijck et al. 2006). However, the potential effects of climate change on groundwater and groundwater sustainability are poorly understood. Gleeson et al. (2012) considered groundwater sustainability to include environmental, economic, or social consequences over multigenerational time scales (50-100 years). The relation between climate variables and groundwater is considered more complicated than with surface water (Holman 2006; IPCC 2007b). This understanding is confounded by the fact that groundwater-residence times can range from days to tens of thousands of years, which delays and disperses the effects of climate change, and challenges efforts to detect responses in the groundwater (Chen et al. 2004). 


\subsubsection{Precipitation, Evapotranspiration, and Surface Water Affect Groundwater}

Precipitation and evapotranspiration are particularly important because they directly affect groundwater recharge and indirectly affect human groundwater withdrawals or discharge. Even small changes in precipitation may lead to large changes in recharge in some semiarid and arid regions (Green et al. 2007; Sandstrom 1995; Woldeamlak et al. 2007). The current section describes recent research findings regarding how atmospheric and surface-water changes will generally affect subsurface hydrologic processes in the soil and vadose zone that control infiltration and recharge to groundwater resources.

Global warming is expected to increase the spatial variability in projected precipitation producing both positive and negative changes in regional precipitation, as well as changes in seasonal patterns (Cook et al. 2014; IPCC 2007b). There is little agreement on the direction and magnitude of predicted evapotranspiration patterns (Barnett et al. 2008). However, higher air temperatures are likely to increase evapotranspiration, which may result in a reduction in runoff and SWC in some regions (Chiew and McMahon 2002). In temperate regions where plants senesce during the winter, groundwater recharge and stream baseflow could be less affected than evapotranspiration would infer due to the seasonal timing of recharge events (e.g., Hunt et al. 2013). In seasons of above average precipitation, recharge is likely to increase, and water demand, such as for irrigated agriculture, will decline because of lower temperature and solar radiation and higher humidity in such periods (Rosenberg et al. 1999). In contrast, the spatial extent and temporal duration of extreme drought are predicted to increase under future climate change (Bates et al. 2008; IPCC 2007b).

The increased variability in precipitation, temperature, and evapotranspiration that is predicted under many climate-change scenarios will likely have variable effects on different aquifers and different locations within an aquifer depending on spatial variability in hydraulic properties and distance from the recharge area(s). Chen et al. (2002) observed that groundwater levels responded to precipitation variability in a mid-continent carbonate-rock aquifer differently from well to well because of the spatial differences in permeability of overlying sediments and recharge characteristics. Additionally, groundwater levels at some locations of the aquifer responded to high-frequency precipitation events while groundwater levels in other areas did not respond. The groundwater-level response to highfrequency events may indicate the existence of highly permeable channels or preferential-flow paths from land surface to the water table (Chen et al. 2002), or differences in thickness of the unsaturated zone (e.g., Hunt et al. 2008).

Other studies indicate that even modest increases in near-surface air temperatures will alter the hydrologic cycle substantially in snowmelt-dominated regions. Seasonal streamflow is altered because the snowpack acts as a reservoir for water storage (Barnett et al. 2008; Cayan et al. 2001; Hunt et al. 2013; Mote et al. 2005; Stewart et al. 2004; Tague et al. 2008). For example, Eckhardt and Ulbrich (2003) predicted a smaller proportion of the winter precipitation will fall as 
snow due to warming trends in mountainous regions of central Europe and that the spring-snowmelt peak will likely be reduced while the flood risk in winter will probably increase. Unless additional reservoir storage is created to account for the earlier snowmelt runoff, the use of groundwater may increase, where available, to offset the lack of surface water later in the season when water demands are typically higher.

Spatial differences in groundwater dynamics in mountainous regions also can play a substantial role in determining streamflow responses to warming (Tague et al. 2008; Tague and Grant 2009). Tague et al. (2008) suggested that groundwater dynamics, such as subsurface drainage, are as important as topographic differences in snow regimes in determining the response of mountain landscapes to climate change. The changes in streamflow, shifting spring and summer streamflow to the winter, will likely increase competition for reservoir storage and in-stream flow for endangered species (Payne et al. 2004) and lead to summer water shortage throughout the western United States (Tague et al. 2008) and other similar semiarid and arid regions globally.

In mountainous regions, how will forecasted changes to the surface hydrologic regime affect infiltration, evapotranspiration, SWC distribution, and ultimately recharge? Singleton and Moran (2010) noted that recharge mechanisms, storage capacity, and residence times of high elevation aquifers are poorly understood. The net change in recharge in mountain aquifers due to changes in the timing of snowpack melting is generally not known in direction or magnitude, making it difficult to predict the response of mountain groundwater systems to climate change (Singleton and Moran 2010). How will mountain-front recharge and recharge in other types of mountainous systems be affected by predicted changes in the snowmelt-dominated regions? A negative feedback between early timing of snowmelt and evapotranspiration may exist in snowmelt-dominated watersheds, as earlier snowmelt increases SWC in the season when potential evapotranspiration is relatively low (Barnett et al. 2008), which may increase infiltration and recharge in mountainous regions. Later in the year, when potential evapotranspiration is greater, the shift in snowmelt timing may reduce SWC, which again reduces the effect of evapotranspiration change but has an unknown effect on net infiltration and recharge. These and other questions remain regarding subsurface hydrologic responses to climate-change effects on surface-water hydrology.

\subsubsection{Soil Water and Vadose Zone Hydrology}

Climate-related variables that have a substantial control on soil water include spatiotemporal patterns in precipitation, evapotranspiration, and surface-water conditions. Land use, soil texture, slope, and other biological, chemical, and physical characteristics also are known to affect SWC (Jasper et al. 2006) with associated effects on groundwater and baseflow to streams (Wang et al. 2009). Seneviratne et al. (2010) provided an extensive review of interactions and 
feedbacks between SWC and climate, specifically atmospheric temperature and precipitation.

Climate change and variability are expected to have profound effects on soil water and temperature (Jasper et al. 2006; Jungkunst et al. 2008). Soil water content and temperature are important factors in terrestrial biogeochemical reactions, landatmosphere interactions, and a critical determinant of terrestrial climate. Variability in vadose-zone hydrology, shallow water tables that support SWC, and ultimately infiltration that feeds aquifers are also affected by SWC and temperature (Cohen et al. 2006; Fan et al. 2007). Spatial variations in SWC also influence atmospheric processes, such as the cumulus convective rainfall (Pielke 2001). Jungkunst et al. (2008) noted that some soil types, such as hydromorphic soils (i.e., soils which formed under prolonged periods of water saturation with seasonal aeration), will likely exhibit a higher climate-change feedback potential than other, wellaerated soils because soil organic matter losses in hydromorphic soils are predicted to be much greater than those from well-aerated soils.

Water evaporated from soils and transpired by plants is recirculated into the atmosphere, thus promoting a positive feedback mechanism for precipitation (Salas et al. 2014). The importance of this feedback depends upon the scale of interest. At the global scale, circulation of water between the land, atmosphere, and ocean is obviously important. Simulation of such circulation patterns is the basis for projecting future climates in GCMs. Moving down in scale, the coupling of landatmosphere interactions may become looser. For this reason, hydrologic models are typically driven by measured precipitation without considering feedbacks. However, regional-scale feedback has been shown to account for a "weakly dependent" pattern of annual rainfall via "precipitation recycling" in central Sudan (Elthahir 1989), the Amazon Basin (Eltahir and Bras 1994), and other regions of the world (e.g. Eltahir and Bras 1996). At watershed areas $<90,000 \mathrm{~km}^{2}$, however, the recycling ratio $(\mathrm{P} / \mathrm{ET})$ of a watershed is expected to be less than $10 \%$ based on simple scaling of annual precipitation in the Amazon basin (Eltahir 1993).

Koster et al. (2006) described the Global Land-Atmosphere Coupling Experiment (GLACE) as a model intercomparison study addressing how soil moisture anomalies affect precipitation at the GCM grid-cell resolution over the globe. The simulated strength of coupling between soil moisture and precipitation varied widely, but the ensemble multi-GCM results provided "hot spots" of relatively strong coupling based on a precipitation similarity metric. All studies indicate that the land's effect on rainfall is relatively small, though significant in places, relative to other atmospheric processes.

The vadose zone is the region between the land surface and saturated zone through which groundwater recharge occurs. It comprises complex interactions between thermal-hydrologic-geochemical processes that can affect groundwater quantity and quality. The timing and amount of groundwater recharge can be affected by the thickness of the vadose zone, as simulated for a temperate zone (Hunt et al. 2008). The vadose zone of some semiarid and arid regions responds slowly to terrestrial climate, and its long-term dynamics pose important challenges for understanding of the effects of climate change and variability on the vadose 
zone (Glassley et al. 2003; Phillips 1994). Glassley et al. (2003) showed that vadose-zone pore-water chemistries in the southwestern United States are still adjusting to relatively recent, post-glacial climate changes, and are not at a steady state (Phillips 1994).

\subsubsection{Saturated Zone/Groundwater}

Groundwater is an important component of the global water balance (Chap. 2). The use of groundwater can mitigate droughts, because many aquifers have a large storage capacity and are potentially less sensitive to short-term climate variability than surface-water bodies, which often rely on groundwater discharge to maintain baseflow conditions (Dragoni and Sukhija 2008). However, the ability to use groundwater storage to buffer rainfall deficits that affect surface-water resources will be constrained by the need to protect groundwater-dependent environmental systems (Skinner 2008).

Groundwater has and will continue to respond to changes in climate. Paleoclimate-change conditions and subsequent responses in recharge, discharge, and changes in storage are preserved in the records of groundwater major and traceelement chemistry, stable and radioactive isotope composition, and noble gas content (Bajjali and Abu-Jaber 2001; Castro et al. 2007; Hendry and Woodbury 2007). Other important components of hydrogeological systems include groundwater-fed lakes in arid and semiarid regions (Gasse 2000) and temperate climates (Hunt et al. 2013), pore-water chemistry of the vadose zone (Zuppi and Sacchi 2004), and subsurface-thermal regimes (Miyakoshi et al. 2005; Taniguchi 2002; Taniguchi et al. 2008).

Groundwater acts as a low-pass filter and provides long time-series of reconstructed temperatures and information on atmospheric-moisture transport patterns (Gasse 2000). Hiscock and Lloyd's (1992) paleohydrogeologic reconstruction of the North Lincolnshire Chalk aquifer in England revealed that recharge during the late Pleistocene (approximately the last 140,000 years) has been restricted to periods when the climate and sea-level position were similar to those of the present day. Forest clearance since about 5,000 years ago is likely to have resulted in increased recharge rates and enhanced the rate of Chalk permeability development (Hiscock and Lloyd 1992). Falling global sea levels during the last five glacial periods of the Pleistocene Ice Ages likely resulted in increased hydraulic heads in inland aquifers relative to those in the continental shelf, enhancing groundwater flow toward the coast (Faure et al. 2002). Faure et al. (2002) suggested that the "coastal oases" that formed from the groundwater discharge as springs along the exposed continental shelf had profound effects on biodiversity and carbon storage during periods of severe climatic stress. At present sea levels, submarine groundwater discharge is a well-established phenomenon that contributes substantial mass flux to oceans (Burnett et al. 2006). Gasse (2000) recommended that future paleohydrological research needs to develop solid chronologies, but also to analyze the mechanisms of water storage and losses in aquifers, obtain quantitative 
reconstructions of hydrological cycles, and identify atmospheric-moisture transport patterns at regional scales that affect groundwater resources.

Groundwater resources have been affected by a number of non-climatic forcings, such as contamination, reduction in streamflow (reduction in recharge), and lowering of the water table and decreased storage due to groundwater mining (primarily for irrigated agriculture). Kundzewicz et al. (2007) noted that climaterelated changes to groundwater have been relatively small compared with non-climate drivers. Juckem et al. (2008) demonstrated that changes in landuse influence how climate change is translated to the groundwater system. Additionally, groundwater systems often respond more slowly and have a more substantial temporal lag to climate change than surface-water systems (Chen et al. 2004; Gurdak 2008; Gurdak et al. 2007; Hanson et al. 2004, 2006; Kundzewicz et al. 2007). Persistent and severe dry periods have even altered the hydraulic properties of aquifers, such as the transmissivity of a regional karst aquifer in France (Laroque et al. 1998).

Current vulnerabilities in water resources are strongly correlated with climate variability, due largely to precipitation variability, especially for semiarid and arid regions (Kundzewicz et al. 2007; Ouysse et al. 2010). Such regions are particularly vulnerable to climate change if groundwater reservoirs are small or not available. Even if groundwater resources are currently available, communities become more vulnerable to climate change if the ratio of stored groundwater volumes to recharge is smaller and if there are no other local water resources, such as in the isolated alluvial aquifers of Yemen (van der Gun 2010). Groundwater levels correlate more strongly with precipitation than with temperature, but temperature becomes more important for shallow aquifers (Kundzewicz et al. 2007). The complexity is exacerbated because predictions of global precipitation spatiotemporal patterns are less certain than are predicted temperature patterns. As a result, the IPCC (2007a) stated that there is no evidence for ubiquitous climate-related trends in groundwater.

Green et al. (2011) discussed climate-change effects on components of the groundwater system in some detail, including recharge, discharge, flow and storage, surface-subsurface hydrological interactions, and groundwater quality. These topics are summarized below.

\subsubsection{Groundwater Recharge}

Predicting the dynamics and processes interactions affecting groundwater recharge over time requires a reliable prediction of critical climate variables (Gurdak et al. 2008; Herrera-Pantoja and Hiscock 2008; Jyrkama and Sykes 2007). Recharge occurs via two general pathways in many environments: diffuse recharge to the water table and focused recharge that occurs at locations where surface-water flow is concentrated at the land surface, including stream channels, lakes, topographic depressions, irrigated-agricultural land, and other macropore, preferential-flow pathways (Small 2005). Thus, recharge is a spatially and temporally complex, 
sensitive function of the climate regimes, local geology and soil, topography, vegetation, surface-water hydrology, coastal flooding, and land-use activities (Candela et al. 2009; de Vries and Simmers 2002; Green et al. 2007; Holman 2006; McMahon et al. 2006). Understanding of the controls on recharge is improving (Healy 2010; Scanlon et al. 2002, 2006), but knowledge of recharge rates and mechanisms is often poor (Kundzewicz et al. 2007).

Recharge will be affected by forecasted changes in precipitation patterns. Sharif and Singh (1999) divided groundwater resources into four categories:

1. confined aquifers with upper impermeable layers where recharge primarily occurs from precipitation where the water-bearing formations outcrop at land surface.

2. unconfined (phreatic) aquifers in wet regions where rainfall is high and evapotranspiration is low. These aquifers are highly renewable because precipitation exceeds evapotranspiration throughout much of year.

3. unconfined aquifers in semiarid and arid regions that are likely to have variable annual balances between precipitation and evapotranspiration and a general drying trend under most climate-change forecasts.

4. coastal aquifers vulnerable to rising sea levels (Döll 2009) and salt-water intrusion.

Climate change and variability will likely have variable long-term effects on recharge rates and mechanisms (Aguilera and Murillo 2009; Green et al. 2007; Kundzewicz et al. 2007; Vaccaro 1992). Many climate-change studies have predicted reduced recharge (Herrera-Pantoja and Hiscock 2008); however, the effects of climate change on recharge may not necessarily be negative in all aquifers during all periods of time (Döll 2009; Gurdak and Roe 2010; Jyrkama and Sykes 2007). Case studies (listed chronologically) included various predictions for recharge in Germany (2001), eastern England (2002), western Canada (2004) and Scibek and Allen (2006a), Ontario, Canada (Döll 2009; Gurdak and Roe 2010; Jyrkama and Sykes 2007), western United States (Dettinger and Earman 2007), Russia(Kovalevskii 2007), Australia (Green et al. 2007), and upper Midwestern United States (Hunt et al. 2013). Overall, simulated trends in recharge were highly variable depending upon the base climate zone and combinations of soil and vegetation types.

Temporal climate variability, especially variability in precipitation, can have substantial effects on recharge and groundwater levels. For example, Thomsen (1989) noted that recharge in most of western Denmark at the end of the nineteenth century was only half of the recharge during the period 1964-1983 because of much greater winter rainfall. A similar study of recharge sensitivity in Western Australia by Sharma (1989) concluded that a $\pm 20 \%$ change in rainfall would result in a $\pm 30 \%$ change in recharge beneath natural grasslands and $\pm 80 \%$ change in recharge beneath a pine plantation, indicating that recharge is greatly influenced by land use and precipitation variability. Subsequently, Green et al. (2007) demonstrated the potential importance of changes in the timing of rainfall regimes 
on evapotranspiration and recharge. Eckhardt and Ulbrich (2003) predicted that mean monthly recharge and streamflow will be reduced by up to $50 \%$ under changed precipitation regimes, that may lead to issues of local water quality, groundwater withdrawals, and hydropower generation.

Groundwater recharge and corresponding vulnerability indices have been mapped globally using a simple water balance model (Döll 2009). As noted above, estimates of recharge vary spatially with vegetation, soils and land use, and change in time depending upon the emissions scenario. For the mid-twenty-first century, Döll (2009) estimated that approximately $18 \%$ of the global population would be affected by decreased recharge of at least $10 \%$, and up to a third of the population may experience increased recharge of at least $10 \%$. The latter increases may have pronounced effects in areas with already shallow water tables, which may be more significant than sea level rise in coastal aquifers (Kundzewicz and Döll 2009).

Temperature-depth profiles in deep boreholes are useful for estimating groundsurface temperature history and recharge, because climate change at the ground surface is stored in the subsurface thermal regime (Miyakoshi et al. 2005; Taniguchi 2002). Taniguchi (2002) showed that subsurface thermal profiles near Tokyo, Japan reveal that recharge rates increased from the 1890 s to 1940 s and decreased from the 1940 s to 1990 s, in large part related to climatic variations in the precipitation regime. Climatic conditions affect the direction of groundwater flow and the relation between surface-water bodies and subsurface-water resources. and Dragoni (Cambi and Dragoni 2000; Dragoni and Sukhija 2008; Winter 1999).

Permafrost-groundwater dynamics respond to climate change at many scales, particularly in sub-permafrost groundwater that is highly climate dependent (Haldorsen 2010). Recharge is likely to increase in areas of Alaska that experience permafrost thaw (Dragoni and Sukhija 2008; Kitabata et al. 2006). Additionally, Walvoord and Striegl (2007) proposed that long-term (>30 year) streamflow records of the Yukon River in Alaska indicate a general upward trend in groundwater contribution to streamflow. In the Qinghai-Tibet Plateau of China, groundwater flow may play an important role in permafrost degradation (Cheng and $\mathrm{Wu}$ 2007), where degrading permafrost caused regional lowering of the groundwater table, which has resulted in falling lake levels, shrinking wetlands, and degenerating grasslands. Climate change is expected to reduce snow cover and soil frost in boreal environments of Finland, which will increase winter floods and cause the maximum recharge and water levels to occur earlier in the year in shallow unconfined aquifers (Okkonen et al. 2009; Okkonen and Kløve 2010).

Groundwater is a crucial component of the hydrologic cycle and many waterresource projects. Thus, potential effects of climate change on recharge deserve more attention (Dettinger and Earman 2007). Scientists currently lack the necessary tools and data, such as long-term continuous monitoring of recharge processes to confidently predict recharge responses to future climate change in most environments. In many regions of the world, it is unknown whether recharge will increase or decrease under predicted climate change (Green et al. 2007). The location and timing of recharge and associated effects on groundwater supplies 
are insufficiently understood under future climate change and variability (Gurdak et al. 2007; Sophocleous 2004). However, water resources, especially in many semiarid and arid regions, are particularly vulnerable to the effects of climate change (Aguilera and Murillo 2009; Barthel et al. 2009; Novicky et al. 2010).

\subsubsection{Groundwater Discharge}

Groundwater discharge is the loss of water from an aquifer to a surface-water body, the atmosphere, or abstraction for human uses. Groundwater depletion (see Chap. 3) occurs when rates of groundwater recharge are less than rates of discharge. Over the last 50 years, groundwater depletion from direct or indirect effects of climate change and human activities, such as groundwater pumping for irrigated agriculture or urban centers (Bouraoui et al. 1999; Dams et al. 2007), has expanded from a local issue to one that affects large regions in many countries throughout the world (Alley et al. 2002; Brouyere et al. 2004; Hsu et al. 2007; Martin-Rosales et al. 2007; Moustadraf et al. 2008). Changing global groundwater discharge has even contributed to sea-level rise during the past century (Taylor et al. 2013). In particular, the rise in sea level would have been even greater if substantial quantities of water had not been stored in land-surface reservoirs or channeled into aquifers by irrigation return-flow (Sahagian et al. 1994).

Some groundwater resources could be affected substantially by climate change even if the present groundwater pumping rates are not increased, such as in the Edward aquifer in Texas, USA (Loaiciga et al. 2000) and the Chalk aquifer in eastern England (Yusoff et al. 2002). Direct or indirect effects of climate change on groundwater discharge include soil degradation, changes in water demand, and changes in irrigation or land-use practices (Brouyere et al. 2004).

The notable increase in groundwater depletion beginning in the mid-1900s is consistent with increased population in many regions and the development of highcapacity well pumps that are used to support agricultural industries and public and private drinking-water supplies. For example, parts of the High Plains (or Ogallala) aquifer in the United States have had substantial water-level declines since the 1950s that range from 3 to more than $50 \mathrm{~m}$ depending on the relative magnitudes of discharge and recharge in the aquifer (McMahon et al. 2007). Declining baseflow in the Sand Hills of Nebraska, USA has also been correlated with soil texture (Wang et al. 2009).

Under some climate scenarios, many regions may receive more precipitation. Woldeamlak et al. (2007) showed that under wet-climate scenarios, runoff was the most sensitive component, and when combined with the predicted increases in groundwater discharge, may result in rising groundwater levels and winter precipitation that increase the risk of flooding. Under dry-climate scenarios, recharge was the most sensitive component and decreases in all seasons, resulting in annual groundwater level declines by as much as $3 \mathrm{~m}$. This could have adverse effects on local aquatic life in local wetlands and riverine ecosystems that rely on groundwater discharge to support baseflow (Woldeamlak et al. 2007). 
Submarine groundwater discharge (SGD), or the net groundwater discharge that occurs beneath the ocean, is a large component of the global hydrologic cycle, accounting for as much as $12,000 \mathrm{~km}^{3} /$ year (Speidel and Agnew 1988) and may otherwise provide fresh water for human needs (Burnett et al. 2006; Taniguchi 2000). Quantifying submarine groundwater discharge and the biogeochemical effects on the ocean has important implications for understanding climate-change effects on oceanic processes (Windom et al. 2006). For example, high dissolved nitrogen-phosphorus ratios in SGD relative to surface waters may drive the coastal oceans toward phosphorus limitation within the coming decades, perhaps changing the present nitrogen-limited coastal primary production (Slomp and Van Cappellen 2004; Taniguchi et al. 2008).

\subsubsection{Aquifer Flow and Storage}

Alley (2001) noted the critical importance of groundwater storage in successfully dealing with climate change and variability. In particular, changes in groundwater storage and agricultural groundwater pumping in active semiarid basins are substantial, yet poorly understood, components of the water balance (Ruud et al. 2004). The use of groundwater storage to moderate the effects of drought increases in importance as surface-water storage becomes more limited, especially during drought periods (Alley 2001).

Prior to development, the water in storage of most $\mathrm{s}$ worldwide was based on local-climate conditions, ecological demands, and interactions with surface water. Water-table declines and loss of storage worldwide during the second half of the twentieth century were consistent with the development of high-capacity well pumps, aquifer development for human use, and a warming climate (Kertesz and Mika 1999). Although some regions of the world, including parts of Russia (Dzhamalov et al. 2008), may have sufficiently reliable groundwater storage under future climate change and variability, the rate of global groundwater depletion was approximately $1.6 \times 10^{11} \mathrm{~m}^{3} /$ year during the second half of the twentieth century (Brown 2001). Postel (2001) estimated that if this rate of groundwater depletion continues, the number of people globally that will live in water-stressed countries will increase from 500 million to 3 billion by the year 2025. This problem will likely be compounded by future global-population growth, which correlates with higher groundwater pumping rates that further threaten the groundwater sustainability of many aquifers at the global scale (Loaiciga 2003). Taniguchi et al. (2008) showed that population growth and the associated increase in demand for water resources, groundwater pumping, and temporary loss of groundwater storage, have resulted in substantial land-subsidence problems for many Asian urban centers. Bultot et al. (1988) simulated changes in groundwater storage of three aquifers in Belgium in response to climate change (a doubling of $\mathrm{CO}_{2}$ in their study) that were largely dependent on aquifer specific hydrogeologic properties, such as transmissivity, presence of perched lens, or confining units. 
The water-table declines and loss of groundwater storage in the High Plains aquifer in the United States were consistently large from about the 1940s, when aquifer development became widespread across the aquifer, until about the early 1980s when rates of water-table drawdown diminished. Rosenberg et al. (1999) noted that this turn-around occurred despite a very large increase in the total acreage of irrigated agriculture between the early 1980s and mid-1990s. McGuire (2011) attributed the changes in water tables over this period to more efficient irrigation methods and economic factors, but also to the fact that precipitation in the High Plains was well above normal between 1980 and 1999 (Garbrecht and Rossel 2002).

The responsiveness of the High Plains aquifer, and other similar aquifers, is strongly suggestive that natural and human-induced changes in climate can profoundly affect the availability and future sustainability of groundwater resources. The above-normal precipitation across the High Plains aquifer region between 1980 and the late-1990s can be attributed to teleconnections from natural variations in sea-surface temperatures and atmospheric pressures across the Atlantic and Pacific Oceans (Garbrecht and Rossel 2002). During the 1980s and early 1990s, the Pacific Decadal Oscillation (PDO) (Mantua and Hare 2002) was in the positive phase of variability and the Atlantic Multidecadal Oscillation (AMO) (Kerr 2000) was in the negative phase of variability, which generally results in wetter conditions and lower frequency of drought for the High Plains region (McCabe et al. 2004).

Natural climate variability occurs on all time scales, from annual to decadal, centennial, and millennial time scales. Ghil (2002) noted that the complex nature of climate variability on multiple time scales is a major obstacle to the reliable characterisation of global climate change resulting from human activities. When anthropogenic effects on aquifers are on the same time scale as some natural climate variabilities, it is difficult to distinguish between the two (Gurdak et al. 2007; Hanson et al. 2004; Mayer and Congdon 2008). These natural variations in climate, when combined, can have profound effects on the surface-hydrologic cycle largely because of the magnitude and phase relation that can cause average or extreme climate forcings (Hanson and Dettinger 2005), such as drought, low flow in streams, changes to water quality, and adverse effects on stream ecosystems (Caruso 2002).

As a result, research efforts have characterised subsurface hydrologic and geochemical responses to climate variability on interannual to multidecadal time scales because variability on these time scales has the most tangible implications for water-resource management (Chen et al. 2002, 2004; Gurdak et al. 2007; Hanson and Dettinger 2005; Hanson et al. 2004, 2006). Climate forcings on these timescales, such as the PDO, AMO, and the El Niño/Southern Oscillation (ENSO), substantially control recharge and water-table fluctuations of the High Plains aquifer (Gurdak et al. 2007, 2008, 2009; McMahon et al. 2007), other aquifer systems of the southwestern United States (Barco et al. 2010; Hanson et al. 2006; Hanson et al. 2004), and a number of other aquifers worldwide (Ngongondo 2006), including those in many small, tropical islands in the Pacific, Indian, and Atlantic oceans (White et al. 2007). A few studies have relied on long-term historical 
hydrologic time series to identify climate-variability effects on groundwater levels (Chen et al. 2004; Gurdak et al. 2007; White et al. 2007).

Many questions remain regarding the control of natural climate forcings on subsurface hydrologic processes and how anthropogenic global warming may affect the frequency and magnitude of these forcings. Historical temporal patterns in the hydrologic cycle may not provide a reasonable guide to future climate conditions and hydrologic processes (Bates et al. 2008; IPCC 2007b). Future climate conditions may have substantial consequences for groundwater management and infrastructure (van der Gun 2010). Statistical stationarity of the temporal hydroclimatic dynamics is not a reasonable assumption under climate variability that has low-frequency and internal variability (such as ENSO, PDO, or AMO (McCabe et al. 2004)). Milly et al. (2008) suggested that stationarity assumptions must be replaced by nonstationary conceptual and statistical models for relevant variables in the hydroclimatic system to be properly analyzed. The concept of "shifts" instead of gradual changes in temporal statistics has been applied previously to hydrological systems (Salas and Boes 1980; Salas et al. 2014).

\subsubsection{Surface-Subsurface Hydrological Interactions}

Climate change has substantial implications for surface-water processes (Gosling et al. 2010), including groundwater/surface-water interactions. Some studies suggest that climate change will result in less surface-water availability, which will likely increase the need for groundwater development (Chen et al. 2004; Hsu et al. 2007). For example, climate change may extend the dry season of no or very low flows in some semiarid and arid regions, which can have a substantial effect on the overall water resources of the region if no deep or otherwise reliable groundwater resources are available (Giertz et al. 2006). Surface-water storage structures can play a vital role in augmenting groundwater recharge, especially in semiarid and arid regions (Sharda et al. 2006). Accurate low-flow stream measurements are important for groundwater-fed streams to assess the potential effects of climate change and variability, and to assess in-stream flow requirements and the nature of groundwater-surface interactions (Berg and Allen 2007). Cohen et al. (2006) showed that the responses in surface-water bodies to climate change were controlled in part by groundwater hydrodynamics and position within the watershed; water-table fluctuations were consistent and had larger-amplitude fluctuations with lake levels within the upland portions of a watershed in central Minnesota, USA. Groundwater-supported evapotranspiration varied with topography and aquifer-hydraulic conductivity, and small yet important feedbacks exist between groundwater and atmospheric processes on decadal and longer time scales. Moreover, hydrologic sensitivity of a watershed to climate change depends on feedbacks between groundwater, overland flow, and land-surface water and energy balance (Ferguson and Maxwell 2010) as well as the hydrologic regime such as lakes with and without stream outflows (e.g., Hunt et al. 2013). 
The magnitude and seasonality of groundwater feedbacks to surface hydrologic processes is highly sensitive to climate change (Ferguson and Maxwell 2010).

A projected increase in the frequency of droughts has implications for surfacegroundwater interactions. For example, the summer of 2003 was the hottest in Europe in more than 500 years, linked to an estimated 500 deaths in the Netherlands alone, but this could become a close-to-normal summer by about 2050 (Kabat et al. 2005). The extremely low freshwater discharge by the river Rhine in 2003 resulted in groundwater seepage of seawater to the low-lying delta, which threatened substantial areas of Dutch agriculture and horticulture. As a result, studies are underway to develop freshwater canals and additional summer water storage facilities for the region. Across regions of the High Plains aquifer in Kansas, USA, streamflow declines are historically caused by high rates of groundwater pumping, but also correlate with climate variability since the mid-1980s (Brikowski 2008). Projected climate change for the Kansas region will likely continue streamflow declines, resulting in severe consequences for surface-water supply and the strong possibility of unsustainable surface storage of water resources in the region. This will likely create even more pressure on the groundwater resources of the already-stressed High Plains aquifer. Similar findings have been identified in other climate regions, including humid, tropical and arctic catchments. Both observations and modelling suggest that climate-warming induced permafrost degradation will markedly increase baseflows of arctic and subarctic rivers and streams (Bense et al. 2009; St. Jacques and Sauchyn 2009; Walvoord and Striegl 2007).

Understanding future climate change effects will be crucial, especially for groundwater/surface-water resources already close to the limits of sustainability and under forecasted drought conditions. Groundwater withdrawals can affect streamflow strongly during dry periods (Lee and Chung 2007). Therefore, it is critically important to accurately understand the links between climate change and variations and the cycles of supply and demand that drive recharge and withdrawal of water resources. Accurate projections of climate change and variations and simulations of the responses in the water-resources system are required (Hanson and Dettinger 2005).

\subsubsection{Groundwater Quality}

Most studies of the effects of climate change and variability on groundwater have focused on processes that affect water quantity. Relatively few studies of climate change and variability effects on groundwater have focused on processes that will affect groundwater quality. Groundwater quality is a function of the chemical, physical, and biological characteristics of the resource. Thus, groundwater quality is expected to respond to changes in climate and human activities because of the influences of recharge, discharge, and land use on groundwater systems. The quality of water is related to specific water-use standards. The protection and enhancement of groundwater quality has been a high-priority environmental 
concern because of the direct implications for drinking-water health standards (Alley 1993). Also, water quality may be a limiting factor for other uses of groundwater, such as agriculture, industry, or ecosystem needs. Therefore, sustainability of water supplies under future climate change and variability is not only dependent on the quantity and quality of groundwater resources, but also on the physical hydrogeologic characteristics of the aquifer, laws, regulations, and socioeconomic factors that control the demand and use of groundwater (Reilly et al. 2008).

Global change may affect the quality of groundwater in many ways (Alley 2001; Dragoni and Sukhija 2008). Changes to recharge rates, mechanisms, and locations can affect contaminant transport, which may lead to erroneous conclusions about temporal trends in groundwater quality, particularly if only a few samples have been collected over time (Alley 2001). For example, recharge during relatively dry periods may have a greater concentration of salts and total-dissolved solids (TDS), while recharge during relatively wet periods may have a relatively lower TDS concentration (Sukhija et al. 1998). Climate variability on interannual to multidecadal timescales has been linked with changes in spatiotemporal-precipitation patterns that can result in substantial infiltration events that mobilise large, porewater chloride and nitrate reservoirs in the vadose zone of aquifers in semiarid and arid regions (Gurdak et al. 2007, 2008). Groundwater quality may deteriorate substantially if these large chemical reservoirs reach the water table.

Coastal regions support approximately one-quarter of the global population, but contain less than $10 \%$ of the global-renewable water supply and are undergoing rapid-population growth (Kundzewicz et al. 2007). Sea-level rise, spatiotemporal changes in precipitation and evapotranspiration, which affect recharge, and increased groundwater pumping will likely result in more groundwater salinisation in many coastal regions (Barrocu and Dahab 2010; Beuhler 2003; IPCC 2007a; Klein and Nicholls 1999; Kundzewicz et al. 2007; Moustadraf et al. 2008; Oude Essink 1996; Oude Essink 2001, 2004; Oude Essink et al. 2010; Pierson et al. 2001; Ranjan et al. 2006a, b; Sharif and Singh 1999; Yechieli et al. 2010). Vandenbohede et al. (2008) simulated a likely $15 \%$ increase in recharge across a Belgian coastal aquifer over the next 100 years. A $0.4 \mathrm{~m}$ sea-level rise increased simulated groundwater flow of fresh water toward low-lying inland areas and decreased groundwater flow toward the sea, while the increase in recharge resulted in more groundwater flow toward both low-lying inland areas and the sea. Therefore, brackish and salt water present in low-lying areas will be pushed back. Salt-water intrusion may occur from the low-lying areas into dunes, which could affect the ecology of the dunes and the drainage system used in most low-lying areas (Vandenbohede et al. 2008).

Lambrakis and Kallergis (2001) showed that over-pumping, combined with a dry period, has led to a substantial decline in groundwater quality of many Greek coastal aquifers. When simulated groundwater pumping was discontinued, the reverse process of groundwater freshening was a relatively long process, ranging from 15 to 10,000 years depending on the local geochemical conditions and flow regime (Lambrakis and Kallergis 2001). Such long periods of groundwater 
freshening highlight the importance of minimising the initial saltwater intrusion. The salinisation of groundwater may, in turn, affect the water quality in many rivers and estuaries (Burkett et al. 2002). Due to increasing human population, agricultural development and economic activities, the shortage of fresh groundwater for domestic, agricultural, and industrial purposes becomes more striking in coastal low-lying deltaic areas like the Mississippi, Nile, Mekong, Ganges, Po, and RhineScheldt deltas (Oude Essink 1996).

Reduced groundwater recharge and increased pumping may disrupt the current balance of the freshwater/saline water boundary, resulting in saline water intrusion in coastal basins, and even inland aquifers, such as the carbonate rock aquifer in the Winnipeg region of Canada (Chen et al. 2004; Grasby and Betcher 2002). Increased groundwater pumping could induce upward leakage of groundwater with poorerwater quality, such as in the High Plains aquifer (McMahon et al. 2007). Alley (2001) also noted that the combined effects of groundwater development and climate change may lead to less dilution of contaminants in streams during low flow (baseflow from groundwater) than was assumed in setting stream-discharge permits.

A wide range of additional climate-change effects on groundwater quality are possible. Kovalevskii (2007) showed that under projected climate change, many regions of Russia will likely have increased rates of recharge that may increase rates of contaminant transport and groundwater vulnerability to various distributed and point-source contamination. The combination of the heat-island effect from urbanisation and global warming on subsurface temperatures has implications for groundwater quality because of changes to subsurface biogeochemical reactions (Knorr et al. 2005; Taniguchi et al. 2008). Additional research is needed to understand and predict the full range of effects on groundwater quality from changes in the subsurface thermal regime and various biogeochemical reactions (Aureli and Taniguchi 2006). Climate change and the global trend of increasing urbanisation may also increase flood vulnerability (Aureli and Taniguchi 2006). Flooding in urban areas could increase loading of common urban contaminants like oil, solvents, and sewage to groundwater.

Nutrient transport rates beneath agricultural lands may also be sensitive to climate change. A study of nitrogen $(\mathrm{N})$ and phosphorus $(\mathrm{P})$ in Sweden (Destouni and Darracq 2009) illustrated subsurface controls on nutrient loading to coastal areas that were relatively insensitive to projected climate due to a lagged response to historical nutrient inputs. However, Destouni and Darracq (2009) noted groundwater-induced emissions of greenhouse gases such as $\mathrm{N}_{2} \mathrm{O}$ as a neglected feedback mechanism.

Relatively few studies have explored climate-change effects on pesticide fate and transport in the subsurface. Bloomfield et al. (2006) identified that the main climate drivers for changing pesticide fate and behavior are changes in rainfall seasonality and intensity, and increased temperatures. However, indirect impacts, such as land-use change are likely to have a more substantial effect on pesticides than the direct effects of climate change on pesticide fate and transport. Bloomfield et al. (2006) noted the overall effect of climate change on pesticide fate and 
transport is likely to be highly variable and challenging to predict because of the uncertainties associated with climate predictions.

Long-term monitoring efforts will likely provide the necessary data to observe and understand climate-related spatiotemporal trends in groundwater quality (McMahon et al. 2007; Dragoni and Sukhija 2008). Groundwater-remediation practices may consider climate-change prediction in site design. Warner (2007) noted that climate change, including shifting rainfall patterns, rising sea levels, and fluctuating river levels may affect the potential failure of a fixed-in-place remediation strategy, such as in-situ permeable reactive barrier, to capture its intended plume. The relatively short life expectancy of most engineered groundwaterremediation systems precludes the development of economically viable remediation systems for the long-term and uncertain nature of climate predictions. Warner (2007) suggested that flexibility in design of remediation systems may account for future shifts in the hydraulic gradient caused by climate change, or more likely, from human activities and groundwater pumping.

\subsection{Methods for Investigating Global Change Beneath the Surface}

Green et al. (2011) explored and reviewed a range of techniques for exploring subsurface effects of climate change, which are summarized here. Methods available to detect temporal changes in groundwater quantity and quality are numerous and range markedly in observation scale and "directness" of observation. The most direct, but also smallest-scale observations are obtained from head measurements in piezometers and water quality measurements of water samples obtained in wells. While in-situ measurements arguably provide the most accurate and reliable measures to detect change, spatial variability and transfer of information across scales (i.e., scaling) must be considered. Moreover, observation networks do not exist across large parts of the globe, and installing and maintaining measurement systems is expensive and labor intensive. To evaluate temporal trends at regional to global scales and to study their relationship to change in regional to global climate and human activities, studies of extensive data sets (monitoring networks) of such "point-data" are required. Hydroclimatically similar regions can be explored using a global database of historical climate data. Similarity between historical climates in different regions is a necessary starting point but may not be sufficient to constitute analogous climate change scenarios.

Most hydrogeophysical methods have the advantage that they allow detection of change over larger volumes of the subsurface, but at the expense of detail, notably regarding water chemistry. Remote sensing of systematic change in the recent past and future across the globe has limited ability to "see" watershed-scale groundwater. The major benefit of remote sensing technologies is their ability to access spatial information in remote areas where in-situ monitoring is sparse or non-existent. Furthermore, conjunctive use of well data, hydrogeophysics and remote sensing is essential. 


\subsubsection{Age Dating and Chemical Proxies}

Tracer methods are standard tools of hydrologists to obtain constraints on the age of groundwater and on the processes and conditions experienced during recharge and upon transit in the groundwater system (Clark and Fritz 1997; Cook and Herczeg 2000; Kooi 2008b; Loosli et al. 2001; Plummer 1993). Age dating refers to methods that aim to constrain the timing of recharge, often via the time since recharge. Groundwater ages can be estimated using radioactive isotopes with well-known, stable source concentrations (e.g., ${ }^{14} \mathrm{C}$ ), radioactive isotopes with variable source concentration and a daughter isotope that can be fairly uniquely linked to the mother species (e.g., ${ }^{3} \mathrm{H} /{ }^{3} \mathrm{He}$ ), or conservative chemical species which exhibit negligible decay and which have a well-known, systematically changing source concentration (e.g., ${ }^{85} \mathrm{Kr}, \mathrm{CFC}$ 's, $\mathrm{SF}_{6}$ ).

These "direct methods" of age dating, in principle, allow construction of a continuous record of water age with distance along a flow path, thereby potentially revealing temporal changes in recharge. Accuracy of age-dating methods covering time scales of 100-500 years is low, making temporal changes in this age-range difficult to resolve.

Several "indirect" age-dating methods provide additional useful constraints on groundwater age. These methods generally determine whether a water sample is recharged before or after a known event. An absolute age of a water sample can only be calculated when the sample corresponds to a distinct event marker. The nuclear bomb test peaks in ${ }^{3} \mathrm{H},{ }^{14} \mathrm{C}$ and ${ }^{36} \mathrm{Cl}$ are key examples. These indirect methods are most useful to study spatial variability in groundwater flow systems.

Several chemical proxies are used to trace changes in groundwater flow and changes in recharge conditions associated with climate change and surface environmental change in general. Key proxies are the stable isotopes of water (Clark and Fritz 1997) and noble gases dissolved in groundwater (Porcelli et al. 2002; Stute and Schlosser 1993). Also, chloride content of groundwater and, in particular in vertical SWC profiles collected in thick vadose zones in desert areas, have been exploited to infer changes in recharge conditions (e.g. Edmunds and Tyler 2002). Although noble gases have been applied primarily in paleohydrological reconstructions of long time scales (Kooi 2008a), they should also provide valuable constraints regarding changes in groundwater systems on timescales of decades to centuries.

\subsubsection{Hydrogeophysical Techniques}

Three hydrogeophysical methods are particularly relevant to the study of groundwater and the changes that arise from climate variability and change:

1. electrical/electromagnetic methods,

2. subsurface temperature logging, and

3. land-based gravity surveying. 
A wide range of electrical/electromagnetic imaging and logging methods can be used to study groundwater systems and their responses to climate-related phenomena. This group of methods includes spontaneous/self potential (SP), electrical resistivity, induced polarisation (IP), a range of time and frequency domain electromagnetic methods, and ground-penetrating radar (GPR). Their advantage over point sampling is that large areas can be covered either in land-based surveys or airborne surveys. Borehole logging methods can be used in a similar fashion to provide vertical profiles of these properties with depth and to constrain survey data.

Perhaps the most common application of these methods is to studies of saline water in aquifers (Dent 2007). Climate change is expected to result in higher sea levels, posing an even greater threat to coastal aquifers. Thus, these hydrogeophysical methods are ideally suited for monitoring changes in groundwater salinity over large coastal areas due to the effects of sea level rise. These techniques may prove invaluable for detecting changes in salinity over broad agricultural areas.

Subsurface temperature can be used to reconstruct climate change and land cover change, because the signal of surface temperature change is preserved in subsurface environment (e.g., Chapman et al. 1992; Davis et al. 2010; GonzálezRouco et al. 2009). Changes in surface temperature associated with changes in air temperature (Smerdon et al. 2009) can propagate into the subsurface, and can be detected by measuring ground temperatures up to several hundred meters deep (Beltrami and Mareschal 1995; Čermák et al. 1992). Temperature-depth profiles collected in boreholes can reveal and be used to help reconstruct the surface temperature changes due to climate change and land cover change during a few to several hundred years (Beltrami 2002; Huang et al. 2000; Roy et al. 2002). Effects of global warming on subsurface temperature subsequently affect the ecology and water quality.

Land-based gravity measurements have been used to detect changes in groundwater storage. Pool and Eychaner (1995) observed that measured gravity changes of about 13 microGal represented storage changes of about $0.30 \mathrm{~m}$ of water. Gravity meters are now sufficiently accurate to measure variations of about 2 microGal, and finer instrumental precision with temporal averaging. Gravity measurements have also been used to detect the changes in groundwater storage in situ (gravity profiling) and using the GRACE satellite data as discussed in the next section.

\subsubsection{Remote Sensing of Space-Time Trends}

Satellite remote sensing (RS) represents the most powerful method for detection and monitoring of environmental and climate change on a global scale. However, capabilities of RS to "look below the ground surface" and to detect properties that directly bear on groundwater conditions are extremely limited. Notable exceptions to this are satellite-based observations of the gravity field associated with changes in groundwater storage.

Remote sensing and earth observation technologies provide an important means of collecting groundwater-related data on a regional scale and to assess the state of 
the resource. Satellite remote sensing, despite drawbacks of temporal frequency and estimation errors, offers the advantages of global coverage, availability of data, metadata, error statistics, and the ability to provide meaningful spatial averages.

Aerial thermal infrared imaging is being used for mapping groundwater discharge zones in estuaries, rivers and oceans. Peterson et al. (2009) used aerial thermal infrared imaging to reveal that submarine groundwater discharge (SGD) along the western coast of the Big Island of Hawaii is often focused as point-source discharges that create buoyant groundwater plumes that mix into the coastal ocean.

Landsat, the Moderate-resolution Imaging Spectroradiometer (MODIS), the Advanced Very High Resolution Radiometer (AVHRR), and certain other instruments can resolve the location and type of vegetation, which can be used to infer a shallow water table. Altimetry measurements and Interferometric Synthetic Aperture Radar (InSAR) over time can show where subsidence is occurring, which is often an indicator of groundwater depletion. Microwave radar and radiometry measurements can be used to estimate snow and surface soil water, which further constrain groundwater assessments.

Perhaps the most valuable remote sensing technology for groundwater investigations is satellite gravimetry employed by the Gravity Recovery and Climate Experiment (GRACE) - a satellite gravimetry technology that may be used to assess groundwater storage changes. Since its launch in 2002, the GRACE satellites have been employed to detect tiny temporal changes in the gravity field of the Earth (Ramillien et al. 2008). Temporal changes in measured gravity are primarily caused by changes in total water (mass) storage (TWS) in the atmosphere, ocean and at and below the surface of the continents. GRACE is being used to generate time series of total terrestrial water variations (Tapley et al. 2004), which can be used to assess groundwater storage changes. Wahr et al. (2006) presented the first technique for deriving terrestrial water storage variations from global gravity field solutions delivered by GRACE. Rodell and Famiglietti (2002) showed in a pre-GRACElaunch study that interannual variations and trends in the High Plains aquifer water storage would be detectable by GRACE, pointing to new opportunities for groundwater remote sensing. Rodell et al. (2007) developed time series of groundwater storage variations averaged over the Mississippi River basin and its four major sub-basins using in situ data, and used these to evaluate GRACE-based estimates in which SWC and snow water equivalent fields output from a sophisticated land surface model were used to isolate groundwater from the GRACE terrestrial water storage data. At the smaller spatial scale of Illinois $\left(145,000 \mathrm{~km}^{2}\right)$, Swenson et al. (2006) showed that GRACE captures the signal of changes in total water storage very well, while Yeh et al. (2006) showed that GRACE-based estimates of groundwater storage variations compared well with borehole observations on seasonal timescales. Swenson et al. (2008) used Oklahoma Mesonet data and local groundwater level observations to further refine methods to remove the SWC signal from the total water storage change signal recorded by GRACE.

Post-launch studies using GRACE data have demonstrated that when combined with ancillary measurements of surface water and SWC, GRACE is capable of monitoring changes in groundwater storage with reasonable accuracy (temporal 
resolution 10 days to monthly, spatial resolution $400-500 \mathrm{~km}$, mass change $\sim 9 \mathrm{~mm}$ water equivalent). Syed et al. (2008) also found agreement between the storage changes estimated by GRACE and the Global Land Data Assimilation System (GLDAS), where GLDAS was used to disaggregate terrestrial water storage between soil, vegetation canopy and snow.

The need to better quantify potential changes in the water cycle associated with climate change $\left(\mathrm{GEWEX}^{1}\right.$; WATCH program $^{2}$ ) has provided a major stimulus for improvement of techniques to monitor key variables and components of the hydrological cycle using space-based platforms. Advances and new developments in monitoring of soil moisture (de Jeu et al. 2008; Liu et al. 2009), precipitation, and evapotranspiration (Anderson and Kustas 2008; Kalma et al. 2008) provide crucial elements to help constrain space-time trends in groundwater recharge. Future research will undoubtedly focus on the further integration of these multi-platform and multi-parameter observations, including GRACE data, in extensive hydrological models. Recent dedicated hydrological missions for improved monitoring of soil moisture (2009: SMOS/ESA; 2011: SMAP/NASA) and precipitation (2012: GPM/NASA) enhance RS capabilities of groundwater resources assessment.

The monthly temporal resolution of GRACE is an issue for many applications, but it should be sufficient for regional groundwater assessments. To address such scale issues, Zaitchik et al. (2008) used an advanced data assimilation approach to incorporate GRACE data into a land surface model, and hence merge them with other datasets and our knowledge of physical processes as represented in the model. In simulations over the Mississippi River basin, the GRACE-assimilation groundwater storage output fit observations better than output from the open loop, and they were of much higher spatial and temporal resolution than GRACE alone. Yamamoto et al. (2008) reported the larger difference, in particular at low latitude regions, between current terrestrial water models of global river basins and GRACE data. This technique may be the key to maximising the value of GRACE data for groundwater resources studies (e.g., Fukuda et al. 2009).

\subsection{Assessments of Subsurface Hydrology: Numerical Simulations}

Mathematical groundwater models play a central role, both for interpreting and integrating data and for generating general insight to the response of groundwater systems to climate change and other forcings on multiple spatial and temporal scales. While observations are essential to explore and document subsurface global change, numerical models provide key tools, not only to assist in developing a process-based understanding of observed changes (i.e., hindcasting), but also

\footnotetext{
${ }^{1}$ http://www.gewex.org/

${ }^{2}$ http://www.eu-watch.org/
} 
predict the future response of the subsurface parameters to climate change, land-use change and water management scenarios (forecasting). Distributed groundwater models simulate flow in the subsurface, both in saturated and unsaturated conditions, as well as for porous and fractured media. Specialised codes are used to simulate chemical processes, such as solute transport and reactions, heat transport, and density-dependent flow (e.g., for coastal regions). In addition to groundwater models, which form the basis for groundwater assessment, other potential models include coupled land surface-atmospheric models, biogeochemical models, surface-water hydrological models, coupled surface-water/groundwater models, and coupled land surface and variable-saturated groundwater models.

Process-based continental or global-scale hydrological models are rare. Thus, most studies develop watershed or smaller scale models, which are better constrained by available data and, thus, more easily calibrated. However, there remain challenges for coupling GCM predictions with hydrological models (Scibek and Allen 2006b; Toews and Allen 2009; Xu 1999), including issues discussed in the section Global Climate Projection.

The appropriate level of model complexity for a given problem may remain subjective, but some level of process interaction within the plant-soil-groundwateratmospheric system must be present. Tietjen et al. (2009) made a case for at least two soil layers in a soil-vegetation model that simulated soil-water dynamics under different climatic conditions. Others have applied relatively complex, spatially distributed subsurface models and coupled surface-groundwater models (Goderniaux et al. 2009; Hunt et al. 2013; van Roosmalen et al. 2007, 2009).

Numerical model-based studies continue to improve, but for the most part, the approaches are similar to the limited examples given above and more comprehensive case studies discussed by Green et al. (2011). Models used to predict terrestrial and subsurface effects of climate change must incorporate appropriate processes and their interactions in space and time. Integration studies encompassing changes in human or socio-economic scenarios (apart from emissions scenarios), such as land use and water demand are generally lacking (Holman 2006).

\subsection{The Role of Groundwater in the Water-Food-Energy- Climate Nexus}

Food and energy are inextricably linked through water in many important ways (see also Chap. 4). In most regions, agriculture uses a dominant share of water, often based on senior (possibly "grandfathered") water rights. Urban areas and industries, including the energy sector, have growing water demands and substantial financial resources that often lead to purchases of water rights from agricultural stakeholders. Thus, the price of water tends to rise from the demand side. In many water limited areas, projected reductions in supply will further raise prices. In this way, climate change enters the water-food-energy nexus as an additional complicating factor.

Various organisations and funding agencies are aiming to address the waterfood-energy nexus, by this or another term, including integrated modeling (Bazilian 
et al. 2011). A book by the World Economic Forum (Waughray 2011) covers the water-food-energy-climate nexus, including some discussion of groundwater issues. The interactive nature of problems related to this nexus will continue to spawn interest and exploration, hopefully with new innovations.

\subsection{Adapting to Climate Change: Integrated Groundwater Management}

Climate adaptation measures are developed to cope with the consequences of a changing climate and reduce future risks. Adaptation encompasses both national and regional strategies as well as practical measures taken at all political levels and by individuals.

In many parts of the world, groundwater is crucial to sustainable development through provision of low-cost, reliable and high-quality water supplies. About $70 \%$ of drinking water in the European Union, $80 \%$ of rural water supply in sub-Saharan Africa and $60 \%$ of agricultural irrigation in India depend on groundwater (IAH 2006). Groundwater also sustains ecosystems and landscapes in humid regions in supporting wetlands and riparian areas, and also supports unique aquatic ecosystems in more arid regions and in coastal environments. The largely hidden nature of groundwater means that development is often untallied and thus uncontrolled and not incorporated into overall water resource management, resulting in over-exploitation and contamination. Thus, even without considering climate change, sustainable management of groundwater is a major challenge. Groundwater is a widely distributed resource responding at basin scales, and local stakeholders (e.g., municipalities, industrial enterprises and farmers) are influenced by national policies determining land and water use. In general, governance systems, resource policies, innovation incentives, data collection and information provision need to relate to a wide range of scales (see Chap. 6), with different adaptive management approaches in rural and urban environments (IAH 2006).

Climate change challenges the traditional assumption that past hydrological experience provides a good guide to future conditions. In times of surface-water shortages during droughts, a typical response is for groundwater resources to be abstracted as an emergency supply. Under conditions of climate change, this response could be unsustainable, especially in areas expected to experience an increase in drought frequency and duration. Also, rising sea levels under climate change will further threaten coastal freshwater aquifers, especially those already experiencing salinisation due to over-exploitation.

Alley (2006) suggested that the effects of discharge and groundwater development often take many years to become evident. Thus, governments tend to neglect the data collection and analysis needed to support informed groundwater management until problems materialize. This type of reactionary stance to groundwater management is flawed because, although some groundwater systems are renewable, many groundwater resources contain "fossil" groundwater and thus are 
nonrenewable natural resources on human time scales. For example, the groundwater that is removed from storage in many arid and semiarid regions was recharged during wetter periods under paleoclimate conditions (Alley et al. 2002).

Adaptation approaches can be preventative or reactive and apply to natural and social systems. Ensuring the sustainability of investments in groundwater resources planning and development, over the entire lifetime of a scheme and taking explicit account of changing climate, is referred to as climate proofing (CEC 2007). At a minimum, and in the absence of reliable projections of future changes in hydrological variables, adaptation processes and methods can be implemented, such as improved water use efficiency and water demand management, offering no-regrets options to cope with climate change.

The Netherlands are investing in "climate proofing" (Kabat et al. 2005) that uses hard infrastructure and softer measures, such as insurance schemes or evacuation planning, to reduce the risks of climate change and hydrologic variability to a quantifiable level that is acceptable by the society or economy. The Netherlands and the rest of the world's coastal delta regions are vulnerable to climate change and sea-level rise. Rather than coping with extreme climatic events, as people from all over the world have done over human history, climate proofing is a proactive approach to develop precautionary measures to address the low-probability but high-magnitude hydroclimatologic events forecasted under climate change and variability (Kabat et al. 2005). Climate proofing should be driven by opportunities for technological, institutional, and societal innovations, rather than by the fear of climate-change induced threats. The climate-proofing approach could be used by water-resource scientists, engineers, and managers to develop forward-thinking, innovative solutions and precautionary measures for a range of probable hydroclimatic events under future climate change. The discredited stationarity of hydroclimatology (Milly et al. 2008) may promote innovation and suitable precautionary measures to protect the sustainability of groundwater resources under projected hydroclimatic regimes. Thus the process of adaptation to climate change must itself be adaptive over time.

Potential adaptive responses include some combination of technological (e.g., deepening of existing boreholes), behavioral (e.g., altered groundwater use), managerial (e.g., altered farm irrigation practices), and policy oriented (e.g., groundwater abstractions licensing regulations) approaches. The IPCC (2007a) argued that while most technologies and strategies are studied and developed in certain countries, the effectiveness of various options to substantially reduce risks for vulnerable waterstressed areas is not yet known, particularly at higher levels of warming and related impacts. Shah (2009) noted an indirect feedback of pumping on climate change due to energy use and associated carbon emissions. This is one obvious example of the interactions between potential groundwater-atmosphere feedbacks and adaptation to global change that must be considered.

For integrated water resources management, two types of decisions deal with: (1) new investments, and (2) the operation and maintenance of existing systems. Information is needed about future water availability and demand, both of which are affected by climate change at the river-basin scale (Ballentine and Stakhiv 
1993). As explained by the IPCC (2008), supply-side options generally involve increases in storage capacity or water abstraction. Demand-side adaptation options rely on the combined actions of individuals (industry users, farmers and individual consumers) and may be less reliable. Some options, such as those incurring increased pumping and treatment costs, may be inconsistent with climate change mitigation measures because they involve high energy consumption.

One of the major challenges facing water resources managers is coping with climate change uncertainty, particularly where expensive investment in infrastructure such as well-field design, construction and testing and laying of pipelines is required (Brekke et al. 2004; Taylor et al. 2013). Dessai and Hulme (2007) discussed this challenge and related questions, including: To what amount of uncertainty in climate change should we adapt? Are robust adaptation options socially, environmentally and economically acceptable and how do climate change uncertainties compare with other uncertainties such as changes in demand? The answers to these questions leading to robust adaptation decisions will require the development of probability distributions of specified outcomes (Wilby and Harris 2006) and negotiation between decision-makers and stakeholders involved in the adaptation process (Dessai and Hulme 2007). For lower income countries, availability of resources and building adaptive capacity are particularly important in order to meet water shortages and salinisation of fresh waters.

Examples of current adaptation to observed and anticipated climate change in the management of groundwater resources are few, with groundwater typically considered as part of an integrated water-supply system. Here, three examples serve to highlight the difference in approach in technically-advanced and developing country contexts. The ability of California's water supply system to adapt to longterm climate and demographic changes was examined by Tanaka et al. (2006) using a state-wide economic-engineering optimisation model of water supply management and considering two climate warming scenarios for the year 2100. However, recent drought conditions ${ }^{3}$ raised concerns regarding long-standing issues of groundwater quality and management in California. Even so, the prediction by Tanaka et al. (2006) that California's water supply system appears physically capable of adapting to significant changes in climate and population may remain valid, albeit at significant cost. Such adaptations would entail large changes in the operation of California's large groundwater storage capacity, significant transfers of water among water users and some adoption of new technologies. In the Sacramento Valley, California, Purkey et al. (2007) used four climate time series to simulate agricultural water management with adaptation in terms of improvements in irrigation efficiency and shifts in cropping patterns during dry periods leading to lower overall water demands in the agricultural sector with associated reductions in groundwater pumping and increases in surface-water allocations to other water use sectors. Land-use adaptation to projected climate change may include management changes within land-use classes (e.g., alternative

\footnotetext{
${ }^{3}$ http://www.water.ca.gov/waterconditions/declaration.cfm
} 
crop rotations) or changes in land classification (e.g., converting annual cropping systems to perennial grasslands or forests). Soil and water conservation programs already encourage some of these types of land-use changes.

A similar technological approach to that demonstrated for California is presented for the Mediterranean region of Europe. This region is experiencing rapid social and environmental changes with increasing water scarcity problems that will worsen with climate change. Iglesias et al. (2007) found that these pressures are heterogeneous across the region or water use sectors and adaptation strategies to cope with water scarcity include technology, use of strategic groundwater and better management based on preparedness rather than a crisis approach. Iglesias et al. (2007) also promoted the importance of local management at the basin level but with the potential benefits dependent on the appropriate multiinstitutional and multi-stakeholder coordination.

In contrast to the examples from North America and Europe, Ojo et al. (2003) discussed the downward trends in rainfall and groundwater levels, and increases in water deficits and drought events affecting water resources availability in West Africa. There, the response strategies needed to adapt to climate change emphasize the need for water supply-demand adaptations. The mechanisms needed to implement adaptation measures include: building the capacity and manpower of water institutions in the region for hydro-climatological data collection and monitoring; the public participation and involvement of stakeholders; and the establishment of both national and regional cooperation.

Furthermore, water resources management has a clear association with many other policy areas such as energy, land use and nature conservation. In this context, groundwater is part of an emerging integrated water resources management approach that recognises society's views, reshapes planning processes, coordinates land and water resources management, recognises water quantity and quality linkages, manages surface-water and groundwater resources conjunctively, and protects and restores natural systems while considering of climate change. Also, biofuel production has implications for groundwater recharge quantity and quality (IPCC 2008).

In summary, groundwater resources stored in aquifers can be managed given reasonable scientific knowledge, adequate monitoring and sustained political commitment and provision of institutional arrangements. Although there is no single approach to relieving pressures on groundwater resources, incremental improvements in resource management and protection can be achieved now and in the future under climate change. Sustainable management of groundwater will only be possible by approaching adaptation through the effective engagement of individuals and stakeholders at community, local government and national policy levels. Adaptative decision processes in the face of global change should be addressed even to improve management and decision making in an otherwise unchanging world. That is, natural and human-induced variability under historical conditions will be better quantified and managed using new scientific advances gained under the auspices of global change research, making such work a "winwin" proposition. 


\subsection{Future Directions}

Future work must build upon progress to date, and 12 key issues have been identified to improve understanding and guide integrated groundwater management (IGM) in light of climate change:

1. Knowledge of biophysical processes and their interactions must continue to increase, so that systems will be better understood, and estimates of projected groundwater changes and their potential feedbacks on climate will be refined, including quantification of uncertainty and associated risks.

2. Effects of projected climate change on hydrological fluxes (e.g., groundwater recharge) vary with different combinations of soils/aquifer materials, vegetation, and climate zone.

3. Long-term monitoring of terrestrial systems (groundwater, surface water, vegetation and land-use patterns) must be maintained and fortified to quantify baseline properties.

4. Shifts (versus gradual changes and linear trends) in the temporal means and variances of climate variables are probable forms of climate and groundwater changes which should be evaluated.

5. Higher spatial resolution is needed to make satellite-based gravity measurements more practical for regional groundwater management.

6. Long-term (multidecadal or greater) feedback from groundwater to atmospheric processes constitutes a knowledge gap. Paleohydrology indicates that contemporary groundwater-climate systems are not in equilibrium, due to the long memory of deep groundwater with long flow paths and large storage. Contemporary and projected climate change will have lagged and potentially amplified effects on many groundwater systems.

7. The nexus of climate change with food, water and energy security is linked directly to groundwater in many systems.

8. Issues of food and energy security, environmental protection, and social welfare all interact and depend upon improved understanding of terrestrial responses to climate change and feedback mechanisms.

9. Scaling fluxes of water and its constituents to the domains of interest for management and policy is an overarching theme for projecting groundwater responses and feedbacks with climate.

10. Information from intensive study areas must be transferred across the globe to other areas where monitoring infrastructure and research resources are not available. Mapping of global analogues in terms of climatic and terrestrial properties is a promising first-order approach.

11. Artificial recharge and managed storage and recovery projects may become more important components of many local water systems to bank excess renewable-water supplies

12. IGM needs to be both strategic and flexible over time (tactical) as projected climate-groundwater interactions become certainties, or otherwise unexpected realities. Climate proofing may offer no-regrets options to cope with climate 
change by developing precautionary measures that address low-probability but high-magnitude hydroclimatologic events.

Acknowledgments I wish to thank and acknowledge my colleagues who have contributed to the UNESCO International Hydrological Program's GRAPHIC (Groundwater Resources Assessments under the Pressures of Humanity and Climate change) Project since 2004. In particular, Makoto Taniguchi, Henk Kooi, Jason Gurdak, Diana Allen, Holger Treidel and Alice Aureli, who co-authored Green et al. (2011) contributed substantially to the basis for this chapter, and the authors of Taylor et al. (2013) provided updates and additional insights on key issues related to groundwater and climate change. I also thank Prof. Tony Jakeman and co-editors of this book for inviting me to write this chapter, particularly Dr. Randall Hunt for his thoughtful editing and help integrating it with other chapters.

Open Access This chapter is distributed under the terms of the Creative Commons AttributionNoncommercial 2.5 License (http://creativecommons.org/licenses/by-nc/2.5/) which permits any noncommercial use, distribution, and reproduction in any medium, provided the original author(s) and source are credited.

The images or other third party material in this chapter are included in the work's Creative Commons license, unless indicated otherwise in the credit line; if such material is not included in the work's Creative Commons license and the respective action is not permitted by statutory regulation, users will need to obtain permission from the license holder to duplicate, adapt or reproduce the material.

\section{References}

Aguilera H, Murillo J (2009) The effect of possible climate change on natural groundwater recharge based on a simple model: a study of four karstic aquifers in SE Spain. Environ Geol 57(5): 963-974

Allen DM, Mackie DC, Wei M (2004) Groundwater and climate change: a sensitivity analysis for the Grand Forks aquifer, southern British Columbia, Canada. Hydrogeol J 12(3):270-290

Allen DM, Cannon AJ, Toews MW, Scibek J (2010) Variabiltiy in simulated recharge using different GCMs. Water Resour Res 46:W00F03. doi:10.1029/2009WR008932

Alley WM (1993) Regional ground-water quality. Wiley, New York, 634 pp. ISBN: 978-0-47128453-6

Alley WM (2001) Ground water and climate. Ground Water 39(2):161

Alley WM (2006) Tracking U.S. groundwater reserves for the future? Environment 48(3):10-25

Alley WM, Healy RW, LaBaugh JW, Reilly TE (2002) Flow and storage in groundwater systems. Science 296:1985-1990

Alley WM, Reilly TE, Franke OL (1999) Sustainability of ground-water resources, U.S. geological survey circular 1186. U.S. Geological Survey, Denver, 79 pp

Anderson M, Kustas W (2008) Thermal remote sensing of drought and evapotranspiration. Eos 89(26):233-234

Aureli A, Taniguchi M (2006) Groundwater assessment under the pressures of humanity and climate changes - GRAPHIC. United Nations Educational Scientific and Cultural Organization, Paris

Bajjali W, Abu-Jaber N (2001) Climatological signals of the paleogroundwater in Jordan. J Hydrol 243(1-2):133-147

Ballentine TM, Stakhiv EZ (eds) (1993) Climate change and water resources management. In: Proceedings of the national conference on climate change and water resources management 
(1st), Albuquerque, New Mexico, November 4-7, 1991. US Army Corps of Engineers Institute of Water Resources, Washington D.C.

Barco J, Hogue TS, Girotto M, Kendall D, Putti M (2010) Climate signal propagation in southern California aquifers. Water Resour Res 46:W00F05. doi:10.1029/2009WR008376

Barnett TP, Pierce DW, Hidalgo HG et al (2008) Human-induced changes in the hydrology of western United States. Science 319(5866):1080-1083

Barrocu G, Dahab K (2010) Changing climate and saltwater intrusion in the Nile Delta, Egypt. In: Taniguchi M, Holman IP (eds) Groundwater response to changing climate, International Association of Hydrogeologists selected paper. CRC Press/Taylor and Francis Group, London, pp 11-25

Barthel R, Sonneveld BGJS, Goetzinger J, Keyzer MA, Pande S, Printz A, Gaiser T (2009) Integrated assessment of groundwater resources in the Oueme basin, Benin, West Africa. Phys Chem Earth 34(4-5):236-250

Bates B, Kundzewicz ZW, Wu S, Palutikof JP (2008) Climate change and water, Technical paper VI of the Intergovernmental Panel on Climate Change. Intergovernmental Panel on Climate Change Secretariat, Geneva, $210 \mathrm{pp}$

Bazilian M, Rogner H, Howells M et al (2011) Considering the energy, water and food nexus: towards an integrated modelling approach. Energy Policy 39(12):7896-7906

Bear J, Cheng HD (1999) Seawater intrusion in coastal aquifers - concepts methods and practices. Kluwer, Dordrecht/Boston/London, $625 \mathrm{pp}$

Beltrami H (2002) Climate from borehole data: energy fluxes and temperatures since 1500. Geophys Res Lett 29(23):2111. doi:10.1029/2002GL015702

Beltrami H, Mareschal JC (1995) Resolution of ground temperature histories inverted from borehole temperature data. Global Planet Chang 11(1-2):57-70

Bense VF, Ferguson G, Kooi H (2009) Evolution of shallow groundwater flow systems in areas of degrading permafrost. Geophys Res Lett 36, L22401

Berg MA, Allen DM (2007) Low flow variability in groundwater-fed streams. Can Water Resour J 32(3):227-246

Beuhler M (2003) Potential impacts of global warming on water resources in southern California. Water Sci Technol 47(7-8):165-168

Bloomfield JP, Williams RJ, Gooddy DC, Cape JN, Guha P (2006) Impacts of climate change on the fate and behaviour of pesticides in surface and groundwater - a UK perspective. Sci Total Environ 369(1-3):163-177

Bouraoui F, Vachaud G, Li LZX, Le Treut H, Chen T (1999) Evaluation of the impact of climate changes on water storage and groundwater recharge at the watershed scale. Climate Dynam 15(2):153-161

Brekke LD, Miller NL, Bashford KE, Quinn NWT, Dracup JA (2004) Climate change impacts uncertainty for water resources in the San Joaquin River Basin California. J Am Water Resour Assoc 40(1):149-164

Brikowski TH (2008) Doomed reservoirs in Kansas, USA? Climate change and groundwater mining on the Great Plains lead to unsustainable surface water storage. J Hydrol 354(1-4): 90-101

Brouyere S, Carabin G, Dassargues A (2004) Climate change impacts on groundwater resources: modelled deficits in a chalky aquifer, Geer basin, Belgium. Hydrogeol J 12(2):123-134

Brown L (2001) Running on empty. Forum Appl Res Public Policy 16:1-3

Bultot F, Coppens A, Dupriez GL, Gellens D, Meulenberghs F (1988) Repercussions of a $\mathrm{CO}_{2}$ doubling on the water cycle and on the water balance - a case study for Belgium. J Hydrol 99(3-4):319-347

Burkett VR, Zilkoski DB, Hart DA (2002) Sea-level rise and subsidence: implications for flooding in New Orleans, Louisiana, U.S. geological survey subsidence interest group conference. U.S. Geological Survey, Galveston, pp 63-71

Burnett WC, Aggarwal PK, Aureli A et al (2006) Quantifying submarine groundwater discharge in the coastal zone via multiple methods. Sci Total Environ 367(2-3):498-543 
Cambi C, Dragoni W (2000) Groundwater yield, climate changes and recharge variability: considerations arising from the modelling of a spring in the Umbria-Marche Apennines. Hydrogeologie 4:11-25

Candela L, von Igel W, Javier Elorza F, Aronica G (2009) Impact assessment of combined climate and management scenarios on groundwater resources and associated wetland (Majorca, Spain). J Hydrol 376(3-4):510-527

Caruso BS (2002) Temporal and spatial patterns of extreme low flows and effects on stream ecosystems in Otago, New Zealand. J Hydrol 257(1-4):115-133

Castro MC, Hall CM, Patriarche D, Goblet P, Ellis BR (2007) A new noble gas paleoclimate record in Texas - basic assumptions revisited. Earth Planet Sci Lett 257(1-2):170-187

Cayan DR, Kammerdiener SA, Dettinger MD, Caprio JM, Peterson DH (2001) Changes in the onset of spring in the Western United States. Bull Am Meteorol Soc 82:399-415

CEC (2007) Adapting to climate change in Europe - options for EU action. Green paper from the Commission to the Council, the European Parliament, the European Economic and Social Committee and the Committee of the Regions, Commission of the European Communities, Brussels

Čermák V, Bodri L, Šafanda J (1992) Underground temperature fields and changing climate: evidence from Cuba. Global Planet Chang 5(4):325-337

Chapman DS, Chisholm TJ, Harris RN (1992) Combining borehole temperature and meteorologic data to constrain past climate change. Global Planet Chang 6(2-4):269-281

Chen Z, Grasby SE, Osadetz KG (2002) Predicting average annual groundwater levels from climatic variables: an empirical model. J Hydrol 260(1-4):102-117

Chen Z, Grasby SE, Osadetz KG (2004) Relation between climate variability and groundwater levels in the upper carbonate aquifer, southern Manitoba. Can J Hydrol 290(1-2):43-62

Cheng G, Wu T (2007) Responses of permafrost to climate change and their environmental significance, Qinghai-Tibet Plateau. J Geophys Res 112:F02S03. doi:10.1029/2006JF000631

Chiew FHS, McMahon TA (2002) Modelling the impacts of climate change on Australian streamflow. Hydrol Process 16(6):1235-1245

Christensen JH, Hewitson B, Busuioc A et al (2007) Regional climate projections. In: Solomon S et al (eds) Climate change 2007: the physical science basis, Contribution of working group I to the fourth assessment report of the Intergovernmental Panel on Climate Change. Cambridge University Press, Cambridge/New York

Clark I, Fritz P (1997) Environmental isotopes in hydrogeology. Lewis Publishers, Boca Raton/New York, $328 \mathrm{pp}$

Cohen D, Person M, Daannen R et al (2006) Groundwater-supported evapotranspiration within glaciated watersheds under conditions of climate change. J Hydrol 320(3-4):484-500

Cook P, Herczeg AL (2000) Environmental tracers in subsurface hydrology. Kluwer, Norwell, $529 \mathrm{pp}$

Cook BI, Smerdon JE, Seager R, Coats S (2014) Global warming and 21st century drying. Climate Dynam 43:1-21

Dams J, Woldeamlak ST, Batelaan O (2007) Forecasting land-use change and its impact on the groundwater system of the Kleine Nete catchment, Belgium. Hydrol Earth Syst Sci Discuss 4 (6):4265-4295

Davis MG, Harris RN, Chapman DS (2010) Repeat temperature measurements in boreholes from northwestern Utah link ground and air temperature changes at the decadal time scale. J Geophys Res 115:B05203. doi:10.1029/2009JB006875

de Jeu R, Wagner W, Holmes T, Dolman A, van de Giesen N, Friesen J (2008) Global soil moisture patterns observed by space borne microwave radiometers and scatterometers. Surv Geophys 29(4):399-420

de Vries JJ, Simmers I (2002) Groundwater recharge: an overview of processes and challenges. Hydrogeol J 10(1):5-17

Dent D (2007) Environmental geophysics mapping salinity and water resources. Int J Appl Earth Obs Geoinf 9(2):130-136 
Dessai S, Hulme M (2007) Assessing the robustness of adaptation decisions to climate change uncertainties: a case study on water resources management in the East of England. Glob Environ Chang 17(1):59-72

Destouni G, Darracq A (2009) Nutrient cycling and $\mathrm{N}_{2} \mathrm{O}$ emissions in a changing climate: the subsurface water system role. Environ Res Lett 4(3):035008

Dettinger MD, Earman S (2007) Western ground water and climate change - pivotal to supply sustainability or vulnerable in its own right? Ground Water 4(1):4-5

Döll P (2009) Vulnerability to the impact of climate change on renewable groundwater resources: a global-scale assessment. Environ Res Lett 4(3):035006

Dragoni W, Sukhija BS (2008) Climate change and groundwater: a short review, Geological Society special publication. Geological Society, London, pp 1-12

Dzhamalov RG, Zektser IS, Krichevets GN, Safronova TI, Sotnikova LF, Gromova YV (2008) Changes in groundwater runoff under the effect of climate and anthropogenic impact. Water Resour 35(1):15-22

Eckhardt K, Ulbrich U (2003) Potential impacts of climate change on groundwater recharge and streamflow in a central European low mountain range. J Hydrol 284(1-4):244-252

Edmunds WM, Tyler SW (2002) Unsaturated zones as archives of past climates: toward a new proxy for continental regions. Hydrogeol J 10:216-228

Eltahir EAB (1989) A feedback mechanism in annual rainfall in Central Sudan. J Hydrol 110: 323-334

Eltahir EAB (1993) Interactions of hydrology and climate in the Amazon basin. Doctorate thesis, Massachusetts Institute of Technology, Cambridge, MA, $188 \mathrm{pp}$

Eltahir EAB, Bras RL (1994) Precipitation recycling in the Amazon basin. Q J Roy Meteorol Soc 120:861-880

Eltahir EAB, Bras RL (1996) Precipitation recycling. AGU Rev Geophys 34(3):367-378

Emori S, Brown SJ (2005) Dynamic and thermodynamic changes in mean and extreme precipitation under changed climate. Geophys Res Lett 32(17):L17706. doi:10.1029/2005GL023272

Fan Y, Miguez-Macho G, Weaver CP, Walko R, Robock A (2007) Incorporating water table dynamics in climate modeling: 1. Water table observations and equilibrium water table simulations. J Geophys Res 112:D10125

Faure H, Walter RC, Grant DR (2002) The coastal oasis: ice age springs on emerged continental shelves. Global Planet Chang 33(1-2):47-56

Ferguson IM, Maxwell RM (2010) Role of groundwater in watershed response and land surface feedbacks under climate change. Water Resour Res 46:W00F02. doi:10.29/2009WR008616

Fukuda Y, Yamamoto K, Hasegawa T, Nakaegawa T, Nishijima J, Taniguchi M (2009) Monitoring groundwater variation by satellite and implications for in-situ gravity measurements. Sci Total Environ 407(9):3173-3180

Garbrecht JD, Rossel FE (2002) Decade-scale precipitation increase in Great Plains at end of 20th century. J Hydrol Eng 7(1):64-75

Gasse F (2000) Hydrological changes in the African tropics since the last glacial maximum. Quat Sci Rev 19(1-5):189-211

Ghil M (2002) Natural climate variability. In: MacCracken MC, Perry JS (eds) Encyclopedia of global environmental change. Wiley, Chichester

Giertz S, Diekkruger B, Jaeger A, Schopp M (2006) An interdisciplinary scenario analysis to assess the water availability and water consumption in the Upper Oueme catchment in Benin. Adv Geosci 9:3-13

Glassley WE, Nitao JJ, Grant CW, Johnson JW, Steefel CI, Kercher JR (2003) The impact of climate change on vadose zone pore waters and its implication for long-term monitoring. Comput Geosci 29(3):399-411

Gleeson T, Alley WM, Allen DM, Sophocleous MA, Zhou Y, Taniguchi M, Vandersteen J (2012) Towards sustainable groundwater use: setting long-term goals, backcasting, and managing adaptively. Ground Water 50:19-26 
Gleick PH (1986) Methods for evaluating the regional hydrologic impacts of global climatic changes. J Hydrol 88(1-2):97-116

Goderniaux P, Brouyère S, Fowler HJ, Blenkinsop S, Therrien R, Orban P, Dassargues A (2009) Large scale surface-subsurface hydrological model to assess climate change impacts on groundwater reserves. J Hydrol 373(1-2):122-138

González-Rouco JF, Beltrami H, Zorita E, Stevens MB (2009) Borehole climatology: a discussion based on contributions from climate modeling. Clim Past 5(1):97-127

Gosling SM, Taylor RG, Arnell NW, Todd MC (2010) A comparative analysis of projected impacts of climate change on river runoff from global and catchment-scale hydrological model. Hydrol Earth Syst Sci Discuss 7:7191-7229

Grasby SE, Betcher RN (2002) Regional hydrogeochemistry of the carbonate rock aquifer, southern Manitoba. Can J Earth Sci 39:1053-1063

Green TR, van Schilfgaarde J (2006) Watershed approach, encyclopedia of soil science. Taylor \& Francis, London, pp 1874-1878

Green TR, Bates BC, Charles SP, Fleming PM (2007) Physically based simulation of potential effects of carbon dioxide-altered climates on groundwater recharge. Vadose Zone J 6(3): 597-609

Green TR, Taniguchi M, Kooi H, Gurdak JJ, Allen DM, Hiscock KM, Treidel H, Aureli A (2011) Beneath the surface of global change: impacts of climate change on groundwater. J Hydrol 405 (3-4):532-560

Gurdak JJ (2008) Ground-water vulnerability: nonpoint-source contamination, climate variability, and the High Plains aquifer. VDM Verlag Publishing, Saarbrucken

Gurdak JJ, Roe CD (2010) Review: recharge rates and chemistry beneath playas of the High Plains aquifer USA. Hydrogeol J 18(8):1747-1772

Gurdak JJ, Hanson RT, McMahon PB, Bruce BW, McCray JE, Thyne GD, Reedy RC (2007) Climate variability controls on unsaturated water and chemical movement, High Plains aquifer, USA. Vadose Zone J 6(3):533-547

Gurdak JJ, Walvoord MA, McMahon PB (2008) Susceptibility to enhanced chemical migration from depression-focused preferential flow, High Plains aquifer. Vadose Zone J 7(4): $1172-1184$

Gurdak JJ, Hanson RT, Green TR (2009) Effects of climate variability and change on groundwater resources of the United States, U.S. Geological Survey fact sheet 2009-3074. U.S. Geological Survey, Idaho Falls, Idaho, 4 pp.

Gutowski WJ, Vorosmarty CJ, Person M, Otles Z, Fekete B, York J (2002) A coupled landatmosphere simulation program (CLASP): calibration and validation. J Geophys Res 107(D16, 4283): $1-17$

Haldorsen S, Heim M, Dale B, Landvik JY, van der Ploeg M, Leijnse A, Salvigsen O, Hagen JO, Banks D (2010) Sensitivity to long-term climate change of subpermafrost groundwater systems in Svalbard. Quatern Res 73:393-402

Hanson RT, Dettinger MD (2005) Ground water/surface water responses to global climate simulations, Santa Clara-Calleguas Basin, Ventura. Calif J Am Water Resour Assoc 41(3): $517-536$

Hanson RT, Newhouse MW, Dettinger MD (2004) A methodology to assess relations between climatic variability and variations in hydrologic time series in the southwestern United States. J Hydrol 287(1-4):252-269

Hanson RT, Dettinger MD, Newhouse MW (2006) Relations between climatic variability and hydrologic time series from four alluvial basins across the southwestern United States. Hydrogeol J 14(7):1122-1146

Healy RW (2010) Estimating groundwater recharge. Cambridge University Press, Cambridge, $245 \mathrm{pp}$

Hendry MJ, Woodbury AD (2007) Clay aquitards as archives of Holocene paleoclimate: ${ }^{18} \mathrm{O}$ and thermal profiling. Ground Water 45(6):683-691 
Herrera-Pantoja M, Hiscock KM (2008) The effects of climate change on potential groundwater recharge in Great Britain. Hydrol Process 22(1):73-86

Hewitson BC, Crane RG (2006) Consensus between GCM climate change projections with empirical downscaling: precipitation downscaling over South Africa. Int J Climatol 26(10): 1315-1337

Hiscock KM, Lloyd JW (1992) Palaeohydrogeological reconstructions of the North Lincolnshire Chalk, UK, for the last 140,000 years. J Hydrol 133(3-4):313-342

Holman IP (2006) Climate change impacts on groundwater recharge-uncertainty, shortcomings, and the way forward? Hydrogeol J 14(5):637-647

Hsu KC, Wang CH, Chen KC, Chen CT, Ma KW (2007) Climate-induced hydrological impacts on the groundwater system of the Pingtung Plain, Taiwan. Hydrogeol J 15(5):903-913

Huang S, Pollack HN, Po-Yu S (2000) Temperature trends over the past five centuries reconstructed from borehole temperatures. Nature 403:756-758

Hunt RJ, Prudic DE, Walker JF, Anderson MP (2008) Importance of unsaturated zone flow for simulating recharge in a humid climate. Ground Water 46(4):551-560

Hunt RJ, Walker JF, Selbig WR, Westenbroek SM, Regan RS (2013) Simulation of climatechange effects on streamflow, lake water budgets, and stream temperature using GSFLOW and SNTEMP. Trout Lake Watershed. http://pubs.usgs.gov/sir/2013/5159/

IAH (2006) Groundwater for life and livelihoods - the framework for sustainable use. In: 4th World water forum invitation and briefing, Kenilworth

Iglesias A, Garotte L, Flores F, Moneo M (2007) Challenges to manage the risk of water scarcity and climate change in the Mediterranean. Water Resour Manag 21:775-788

IPCC (2007a) Climate change 2007: impacts, adaptation and vulnerability. In: Parry ML, Canziani OF, Palutikof JP, van der Linden PJ, Hanson CE (eds) Contribution of working group II to the fourth assessment report of the Intergovernmental Panel on Climate Change. Cambridge University Press, Cambridge/New York

IPCC (2007b) Climate change 2007: the physical science basis. In: Solomon S et al. (eds) Contribution of working group I to the fourth assessment report of the Intergovernmental Panel on Climate Change. Cambridge University Press, Cambridge/New York, p 996

IPCC (2008) Technical paper on climate change and water. Finalized at the 37th Session of the IPCC Bureau, Geneva

IPCC (2013) Climate change 2013: the physical science basis. In: Stocker TF, Qin D, Plattner G-K, Tignor M, Allen SK, Boschung J, Nauels A, Xia Y, Bex V, Midgley PM (eds ) Contribution of working group I to the fifth assessment report of the Intergovernmental Panel on Climate Change. Cambridge University Press, Cambridge/New York, p 1535

Jasper K, Calanca P, Fuhrer J (2006) Changes in summertime soil water patterns in complex terrain due to climatic change. J Hydrol 327(3-4):550-563

Jorgensen DG, Yasin al-Tikiriti W (2003) A hydrologic and archeologic study of climate change in Al Ain, United Arab Emirates. Global Planet Chang 35(1-2):37-49

Juckem PF, Hunt RJ, Anderson MP, Robertson DM (2008) Effects of climate and land management change on streamflow in the driftless area of Wisconsin. J Hydrol 355(1-4):123-130

Jungkunst HF, Flessa $\mathrm{H}$, Scherber C, Fiedler S (2008) Groundwater level controls $\mathrm{CO}_{2}, \mathrm{~N}_{2} \mathrm{O}$ and $\mathrm{CH}_{4}$ fluxes of three different hydromorphic soil types of a temperate forest ecosystem. Soil Biol Biochem 40(8):2047-2054

Jyrkama MI, Sykes JF (2007) The impact of climate change on spatially varying groundwater recharge in the grand river watershed (Ontario). J Hydrol 338(3-4):237-250

Kabat P, van Vierssen W, Veraart J, Vellinga P, Aerts J (2005) Climate proofing the Netherlands. Nature 438(7066):283-284

Kalma J, McVicar T, McCabe M (2008) Estimating land surface evaporation: a review of methods using remotely sensed surface temperature data. Surv Geophys 29(4):421-469

Keeling CD, Bacastow RB, Bainbridge AE (1976) Atmospheric carbon dioxide variations at Mauna Loa Observatory, Hawaii. TELLUS 28(6):538-551 
Keeling CD, Brix H, Gruber N (2004) Seasonal and long-term dynamics of the upper ocean carbon cycle at station ALOHA near Hawaii. Global Biogeochem Cycles 18(4):1-26

Kerr RA (2000) A North Atlantic climate pacemaker for the centuries. Science 288(5473): 1984-1986

Kertesz A, Mika J (1999) Aridification - climate change in South-Eastern Europe. Phys Chem Earth Solid Earth Geod 24(10):913-920

Kitabata H, Nishizawa K, Yoshida Y, Maruyama K (2006) Permafrost thawing in Circum-Artic and Highlands under climate change scenario projected by community climate system model (CCSM3). Sci Online Lett Atmosphere 2:53-56

Klein RJT, Nicholls RJ (1999) Assessment of coastal vulnerability to climate change. Ambio 28(2):182-187

Knorr W, Prentice IC, House JI, Holland EA (2005) Long-term sensitivity of soil carbon turnover to warming. Nature 433(7023):298-301

Kooi H (2008a) Groundwater palaeohydrology. In: Bierkens MFP, Dolman AJ, Troch PA (eds) Climate and the hydrological cycle, vol 8, IAHS special publication. International Association of Hydrological Sciences, Wallingford, UK, pp 235-254

Kooi H (2008b) Spatial variability in subsurface warming over the last three decades; insight from repeated borehole temperature measurements in the Netherlands. Earth Planet Sci Lett 270: 86-94

Koster RD, 25 others (2006) GLACE: the global land-atmosphere coupling experiment. Part I: overview. J Hydrometeorol 7:590-610

Kovalevskii VS (2007) Effect of climate changes on groundwater. Water Resour 34(2):140-152

Kundzewicz ZW, Döll P (2009) Will groundwater ease freshwater stress under climate change? Hydrol Sci J 54(4):665-675

Kundzewicz ZW, Mata LJ, Arnell NW et al (2007) Freshwater resources and their management. In: Parry ML, Canziani OF, Palutikof JP, van der Linden PJ, Hanson CE (eds) Climate change 2007: impacts adaptation and vulnerability. Cambridge University Press, Cambridge, pp 173-210

Lambrakis N, Kallergis G (2001) Reaction of subsurface coastal aquifers to climate and land use changes in Greece: modelling of groundwater refreshening patterns under natural recharge conditions. J Hydrol 245(1-4):19-31

Laroque M, Mangin A, Razack M, Banton O (1998) Contribution of correlation and spectral analyses to the regional study of a large karst aquifer (Charente, France). J Hydrol 205(3-4): 217-231

Le Treut H, Somerville R, Cubasch U, Ding Y, Mauritzen C, Mokssit A, Peterson T, Prather M (2007) Historical overview of climate change. In: Solomon S, Qin D, Manning M, Chen Z, Marquis M, Averyt KB, Tignor M, Miller HL (eds) Climate change 2007: the physical science basis, Contribution of working group I to the fourth assessment report of the Intergovernmental Panel on Climate Change. Cambridge University Press, Cambridge/New York

Lee KS, Chung ES (2007) Hydrological effects of climate change, groundwater withdrawal, and land use in a small Korean watershed. Hydrol Process 21(22):3046-3056

Leith RMM, Whitfield PH (1998) Evidence of climate change effects on the hydrology of streams in South-Central B.C. Can Water Resour J 23(3):219-230

Liu YY, van Dijk AIJM, de Jeu RAM, Holmes TRH (2009) An analysis of spatiotemporal variations of soil and vegetation moisture from a 29-year satellite-derived data set over mainland Australia. Water Resour Res 45(7):W07405

Loaiciga HA (2003) Climate change and ground water. Ann Assoc Am Geogr 93(1):30-41

Loaiciga HA (2009) Long-term climatic change and sustainable ground water resources management. Environ Res Lett 4(3):035004

Loaiciga HA, Valdes JB, Vogel R, Garvey J, Schwarz H (1996) Global warming and the hydrologic cycle. J Hydrol 174(1-2):83-127

Loaiciga HA, Maidment DR, Valdes JB (2000) Climate-change impacts in a regional karst aquifer, Texas, USA. J Hydrol 227(1-4):173-194 
Loosli HH, Aeschbach-Hertig W, others (2001) Isotopic methods and their hydrogeochemical context in the investigation of palaeowaters. In: Edmunds WM, Milne CJ (eds) Palaeowater in coastal Europe: evolution of groundwater since the late Pleistocene, Geological Society of London special publication 189. Geological Society of London, London, pp 193-212

Lorenz EN (1963) Deterministic nonperiodic flow. J Atmos Sci 20:130-141

Lorenz EN (1975) Climate predictability. In: The physical basis of climate and climate modelling, WMO GARP publication series no 16. WMO, Geneva, pp 132-136

Mantua NJ, Hare SR (2002) The Pacific decadal oscillation. J Oceanogr 58(1):35-44

Martin-Rosales W, Pulido-Bosch A, Vallejos A, Gisbert J, Andreu JM, Sanchez-Martos F (2007) Hydrological implications of desertification in southeastern Spain. Hydrol Sci J 52(6): 1146-1161

Mayer TD, Congdon RD (2008) Evaluating climate variability and pumping effects in statistical analyses. Ground Water 46(2):212-227

McCabe GJ, Palecki MA, Betancourt JL (2004) Pacifica and Atlantic Ocean influences on multidecadal drought frequency in the United States. Proc Natl Acad Sci 101(12):4136-4141

McGuire VL (2011) Water-level changes in the High Plains aquifer, predevelopment to 2009, 2007-08, and 2008-09, and change in water in storage, predevelopment to 2009, U.S. Geological Survey Scientific Investigations report 2011-5089, 13 p, available on the web at http://pubs.usgs.gov/sir/2011/5089/

McMahon PB, Dennehy KF, Bruce BW, Bohlke JK, Michel RL, Gurdak JJ, Hurlbut DB (2006) Storage and transit time of chemicals in thick unsaturated zones under rangeland and irrigated cropland, High Plains United States. Water Resour Res 42:W03314

McMahon PB, Dennehy KF, Bruce BW, Gurdak JJ, Qi SL (2007) Water-quality assessment of the High Plains aquifer, 1999-2004. U.S. Geological Survey. Professional Paper 1749, 136 pp., Reston, Virginia.

Mearns LO, Hulme M, Carter TR, Leemans R, Lal M, Whetton P (2007) Climate scenario development. In: Solomon S, Qin D, Manning M, Chen Z, Marquis M, Averyt KB, Tignor M, Miller HL (eds) Climate change 2007: the physical science basis, Contribution of working group I to the fourth assessment report of the Intergovernmental Panel on Climate Change. Cambridge University Press, Cambridge/New York, pp 739-768

Milly PCD, Dunne KA, Vecchia AV (2005) Global pattern of trends in streamflow and water availability in a changing climate. Nature 438:347-350

Milly PCD, Betancourt JL, Falkenmark M, Hirsch RM, Kundzewicz ZW, Lettenmaier DP, Stouffer RJ (2008) Stationarity is dead: whither water management. Science 319:573-574

Miyakoshi A, Taniguchi M, Okubo Y, Uemura T (2005) Evaluations of subsurface flow for reconstructions of climate change using borehole temperature and isotope data in Kamchatka. Phys Earth Planet In 152(4):335-342

Monnin E, Indermuhle A, Dallenbach A, Fluckiger J, Stauffer B, Stocker TF, Raynaud D, Barnola J-M (2001) Atmospheric $\mathrm{CO}_{2}$ concentrations over the last glacial termination. Science 291:112-114

Mote PW, Hamlet AF, Clark MP, Lettenmaier DP (2005) Declining mountain snowpack in western North America. Am Meteorol Soc 86(1):39-49

Moustadraf J, Razack M, Sinan M (2008) Evaluation of the impacts of climate changes on the coastal Chaouia aquifer, Morocco, using numerical modeling. Hydrogeol J 16:1411-1426

Mudelsee $\mathrm{M}$ (2001) The phase relations among atmospheric $\mathrm{CO}_{2}$ content, temperature and global ice volume over the past $420 \mathrm{ka}$. Quat Sci Rev 20:583-589

Nakićenović N, Swart R (2000) Special report on emissions scenarios, A special report of working group III of the Intergovernmental Panel on Climate Change. Cambridge University Press, Cambridge/New York

Neelin JD, Muennich M, Su H, Meyerson JE, Holloway CE (2006) Tropical drying trends in global warming models and observations. Proc Natl Acad Sci U S A 103(16):6110-6115 
Ngongondo CS (2006) An analysis of long-term rainfall variability, trends and groundwater availability in the Mulunguzi river catchment area, Zomba mountain, southern Malawia. Quat Int 148:45-50

Novicky O, Kasparek L, Uhlik J (2010) Vulnerability of groundwater resources in different hydrogeology conditions to climate change. In: Taniguchi M, Holman IP (eds) Groundwater response to changing climate, International Association of Hydrogeologists. CRC Press/ Taylor \& Francis Group, London, pp 1-10

Ojo O, Oni F, Ogunkunle O (2003) Implications of climate variability and climate change on water resources availability and water resources management in West Africa. In: Franks S, Bloschl S, Kumagai M, Musiake K, Rosbjerg D (eds) Water resources systems - water availability and global change. International Association of Hydrological Sciences, Wallingford, pp 37-47

Okkonen J, Kløve B (2010) A conceptual and statistical approach for the analysis of climate impact on ground water table fluctuation patterns in cold conditions. J Hydrol 388:1-12

Okkonen J, Jyrkama M, Kløve B (2009) A conceptual approach for assessing the impact of climate change on groundwater and related surface waters in cold regions (Finland). Hydrogeol J 18(2):429-439

Oude Essink GHP (1996) Impact of sea level rise on groundwater flow regimes, a sensitivity analysis for the Netherlands. Delft University of Technology, Delft, $411 \mathrm{pp}$

Oude Essink GHP (2001) Salt water intrusion in a three-dimensional groundwater system in the Netherlands: a numerical study. Transp Porous Media 43:137-158

Oude Essink GHP (2004) Modeling three-dimensional density dependent groundwater flow at the island of Texel, the Netherlands. In: Cheng AHD, Ouazar D (eds) Coastal aquifer management: monitoring, modeling, and case studies. Lewis Publisher, New York, pp 77-94

Oude Essink GHP, van Baaren ES, de Louw PGB (2010) Effects of climate change on coastal groundwater systems: a modeling study in the Netherlands. Water Resour Res 46:W00F04. doi:10.1029/2009WR008719

Ouysse S, Laftouhi NE, Tajeddine K (2010) Impacts of climate variability on the water resources in the Draa basin (Morocco): analysis of the rainfall regime and groundwater recharge. In: Taniguchi M, Holman IP (eds) Groundwater response to changing climate, International Association of Hydrogeologists selected paper. CRC Press/Taylor \& Francis Group, London, pp 27-48

Payne JT, Wood AW, Hamlet AF, Palmer RN, Lettenmaier DP (2004) Mitigating the effects of climate change on the water resources of the Columbia River Basin. Clim Chang 62:233-256

Peterson RN, Burnett WC, Glenn C, Johnson A (2009) Quantification of point-source groundwater discharges to the ocean from the shoreline of the Big Island, Hawaii. Limnol Oceanogr 54(3): 890-904

Petit JR, Jouzel J, Raynaud D et al (1999) Climate and atmospheric history of the past 420,000 years from the Vostok ice core, Antarctica. Nature 399(6735):429-436

Phillips FM (1994) Environmental tracers for water in desert soils of the American Southwest. Soil Sci Soc Am J 58:15-24

Pielke RA Sr (2001) Influence of the spatial distribution of vegetation and soils on the prediction of cumulus convective rainfall. Rev Geophys 39(2):151-177

Pierson WL, Nittim R, Chadwick MJ, Bishop KA, Horton PR (2001) Assessment of changes to saltwater/freshwater habitat from reductions in flow to the Richmond River estuary. Aust Water Sci Technol 43(9):89-97

Plummer LN (1993) Stable isotope enrichment in paleowaters of the Southeast Atlantic Coastal Plain, United States. Sci Total Environ 262:2016-2020

Pool DR, Eychaner JH (1995) Measurement of aquifer-storage change and specific yield using gravity surveys. Ground Water 33:425-432

Porcelli D, Ballentine CJ, Wieler R (2002) Noble gases in geochemistry and cosmochemistry, vol 47, Reviews in mineralogy and geochemistry. Geochemical Society and Mineralogical Society of America, Washington, DC

Postel S (2001) Growing more food with less water. Sci Am 284(2):46-51 
Purkey DR, Joyce B, Vicuna S, Hanemann MW, Dale LL, Yates D, Dracup JA (2007) Robust analysis of future climate change impacts on water for agriculture and other sectors: a case study in the Sacramento Valley. Clim Chang 87:S109-S122 Supplement

Ramillien G, Famiglietti JS, Wahr J (2008) Detection of continental hydrology and glaciology signals from GRACE: a review. Surv Geophys 29:361-374

Randall DA, Wood RA, Bony S et al (2007) Climate models and their evaluation. In: Solomon S, Qin D, Manning M, Chen Z, Marquis M, Averyt KB, Tignor M, Miller HL (eds) Climate change 2007: the physical science basis, Contribution of Working Group I to the Fourth Assessment Report of the Intergovernmental Panel on Climate Change. Cambridge University Press, Cambridge/New York, pp 589-662

Ranjan P, Kazama S, Sawamoto M (2006a) Effects of climate change on coastal fresh groundwater resources. Glob Environ Chang 16(4):388-399

Ranjan SP, Kazama S, Sawamoto M (2006b) Effects of climate and land use changes on groundwater resources in coastal aquifers. J Environ Manage 80(1):25-35

Reilly TE, Dennehy KF, Alley WM, Cunningham WL (2008) Ground-water availability in the United States, vol 1323. US Geological Survey, $70 \mathrm{pp}$

Rivard C, Paniconi C, Gauthier MJ, François G, Sulis M, Camporese M, Larocque M, Chaumont D (2008) A modeling study of climate change impacts on recharge and surface-groundwater interactions for the Thomas Brook catchment (Annapolis Valley, Nova Scotia). In: Proceedings of the GeoEdmonton, Canadian Gotechnical Society, International Association of Hydrogeologists, Canadian national chapter joint annual conference, Edmonton

Rodell M, Famiglietti JS (2002) The potential for satellite-based monitoring of groundwater storage changes using GRACE: the High Plains aquifer Central US. J Hydrol 263(1-4): 245-256

Rodell M, Chen J, Kato H, Famiglietti JS, Nigro J, Wilson CR (2007) Estimating groundwater storage changes in the Mississippi River basin (USA) using GRACE. Hydrogeol J 15(1): 159-166

Rosenberg NJ, Epstein DJ, Wang D, Vail L, Srinivasan R, Arnold JG (1999) Possible impacts of global warming on the hydrology of the Ogallala aquifer region. Clim Change 42(4):677-692

Rowell D, Jones R (2006) Causes and uncertainty of future summer drying over Europe. Climate Dynam 27(2):281-299

Roy S, Harris RN, Rao RUM, Chapman DS (2002) Climate change in India inferred from geothermal observations. J Geophys Res B: Solid Earth 107(7):5-1

Ruud N, Harter T, Naugle A (2004) Estimation of groundwater pumping as closure to the water balance of a semi-arid, irrigated agricultural basin. J Hydrol 297(1-4):51-73

Sahagian DL, Schwartz FW, Jacobs DK (1994) Direct anthropogenic contributions to sea level rise in the twentieth century. Nature 367:54-57

Salas JD, Boes DC (1980) Shifting level modeling of hydrologic series. Adv Water Resour 3: $59-63$

Salas JD, Rao GS, Anderson M, Arabi M, Francés F, Suarez W, Lavado-Casimiro WS, Green TR (2014) Introduction to hydrology. In: Wang LK, Yang CT (eds) Modern water resources engineering, Handbook of environmental engineering. Humana Press, New York, pp 1-126

Sandstrom K (1995) Modeling the effects of rainfall variability on groundwater recharge in semiarid Tanzania. Nord Hydrol 26:313-330

Scanlon BR, Healy RW, Cook PG (2002) Choosing appropriate techniques for quantifying groundwater recharge. Hydrogeol J 10(1):18-29

Scanlon BR, Keese KE, Flint AL, Flint LE, Gaye CB, Edmunds WM, Simmers I (2006) Global synthesis of groundwater recharge in semiarid and arid regions. Hydrol Process 20:3335-3370

Scibek J, Allen DM (2006a) Comparing modelled responses of two high-permeability, unconfined aquifers to predicted climate change. Global Planet Chang 50(1-2):50-62

Scibek J, Allen DM (2006b) Modeled impacts of predicted climate change on recharge and groundwater levels. Water Resour Res 42(11):W11405. doi:10.1029/2005WR004742 
Scibek J, Allen DM, Cannon AJ, Whitfield PH (2007) Groundwater-surface water interaction under scenarios of climate change using a high-resolution transient groundwater model. J Hydrol 333(2-4):165-181

Seneviratne SI, Corti T, Davin EL, Hirschi M, Jaeger EB, Lehner I, Orlowsky B, Teuling AJ (2010) Investigating soil moisture-climate interactions in a changing climate: a review. Earth Sci Rev 99(3-4):125-161

Serrat-Capdevila A, Valdes JB, Perez JG, Baird K, Mata LJ, Maddock Iii T (2007) Modeling climate change impacts - and uncertainty - on the hydrology of a riparian system: the San Pedro Basin (Arizona/Sonora). J Hydrol 347(1-2):48-66

Shah T (2009) Climate change and groundwater: India's opportunities for mitigation and adaptation. Environ Res Lett 4(3):035005

Sharda VN, Kurothe RS, Sena DR, Pande VC, Tiwari SP (2006) Estimation of groundwater recharge from water storage structures in a semi-arid climate of India. J Hydrol 329(1-2): 224-243

Sharif MM, Singh VP (1999) Effect of climate change on sea water intrusion in coastal aquifers. Hydrol Process 13(8):1277-1287

Sharma ML (1989) Impact of climate change on groundwater recharge conference on climate and water. Academy of Finland, Helsinki, pp 511-519

Singleton MJ, Moran JE (2010) Dissolved noble gas and isotopic tracers reveal vulnerability of groundwater in a small, high elevation catchment to predicted climate change. Water Resour Res 46:W00F06. doi:10.1029/2009WR008718

Skinner AC (2008) Groundwater: still out of sight but less out of mind. Q J Eng Geol Hydrogeol 41(1):5-19

Slomp CP, Van Cappellen P (2004) Nutrient inputs to the coastal ocean through submarine groundwater discharge: controls and potential impact. J Hydrol 295(1-4):64-86

Small EE (2005) Climatic controls on diffuse groundwater recharge in semiarid environments of the southwestern United States. Water Resour Res 41:W04012

Smerdon JE, Beltrami H, Creelman C, Stevens MB (2009) Characterizing land surface processes: a quantitative analysis using air-ground thermal orbits. J Geophys Res 114(D15):D15102

Sophocleous M (2004) Climate change: why should water professionals care? Ground Water 42(5):637-637

Speidel DH, Agnew AF (1988) The world water budget. In: Speidel DH, Ruedisili LC, Agnew AF (eds) Perspectives on water: uses and abuses. Oxford University Press, New York, pp 27-36

St.Jacques JM, Sauchyn DJ (2009) Increasing winter baseflow and mean annual streamflow from possible permafrost thawing in the Northwest Territories, Canada. Geophys Res Lett 36: L01401

Stewart IT, Cayan DR, Dettinger MD (2004) Changes in snowmelt runoff timing in western North America under a 'business as usual' climate change scenario. Clim Chang 62:217-232

Stute M, Schlosser P (1993) Principles and applications of the noble gas paleothermometer. In: Swart PK, Lohmann KC, McKenzie J, Savin S (eds) Climate change in continental isotopic records, vol 78, Geophysical monograph. American Geophysical Union, Washington, DC, pp 89-100

Sukhija BS, Reddy DV, Nagabhushanam P (1998) Isotopic fingerprints of paleoclimates during the last 30,000 years in deep confined groundwaters of southern India. Quatern Res 50(3): 252-260

Swenson S, Yeh PJF, Wahr J, Famiglietti J (2006) A comparison of terrestrial water storage variations from GRACE with in situ measurements from Illinois. Geophys Res Lett 33(16): L16401. doi:10.1029/2006GL026962

Swenson S, Famiglietti J, Basara J, Wahr J (2008) Estimating profile soil moisture and groundwater variations using GRACE and Oklahoma Mesonet soil moisture data. Water Resour Res 44:W01413. doi:10.1029/2007WR006057

Syed TH, Famiglietti JS, Rodell M, Chen J, Wilson CR (2008) Analysis of terrestrial water storage changes from GRACE and GLDAS. Water Resour Res 44(2):W02433 
Tague C, Grant GE (2009) Groundwater dynamics mediate low-flow response to global warming in snow-dominated alpine regions. Water Resour Res 45(7):W07421

Tague C, Grant G, Farrell M, Choate J, Jefferson A (2008) Deep groundwater mediates streamflow response to climate warming in the Oregon Cascades. Clim Change 86(1-2):189-210

Tanaka SK, Zhu TJ, Lund JR et al (2006) Climate warming and water management adaptation for California. Clim Change 76:361-378

Taniguchi M (2000) Evaluation of the saltwater-groundwater interface from borehole temperature in a coastal region. Geophys Res Lett 27(5):713-716

Taniguchi M (2002) Estimations of the past groundwater recharge rate from deep borehole temperature data. Catena 48(1-2):39-51

Taniguchi M, Burnett WC, Ness GD (2008) Integrated research on subsurface environments in Asian urban areas. Sci Total Environ 404(2-3):377-392

Tapley BD, Bettadpur S, Ries JC, Thompson PF, Watkins MM (2004) GRACE measurements of mass variability in the Earth system. Science 305:503-505

Taylor KE (2001) Summarizing multiple aspects of model performance in a single diagram. J Geophys Res 106:7183-7192

Taylor RG, Scanlon B, Döll P et al (2013) Ground water and climate change. Nat Clim Chang 3(4): 322-329

Thomsen R (1989) The effects of climate variability and change on groundwater in Europe. In: Conference on climate and water. Academy of Finland, Helsinki, pp 486-500

Thoning KW, Tans PP, Komhyr WD (1989) Atmospheric carbon dioxide at Mauna Loa Observatory. 2. Analysis of the NOAA GMCC data, 1974-1985. J Geophys Res 94(D6):8549-8565

Tietjen B, Zehe E, Jeltsch F (2009) Simulating plant water availability in dry lands under climate change: a generic model of two soil layers. Water Resour Res 45(1):W01418

Toews MW, Allen DM (2009) Evaluating different GCMs for predicting spatial recharge in an irrigated arid region. J Hydrol 374(3-4):265-281

Vaccaro JJ (1992) Sensitivity of groundwater recharge estimates to climate variability and change, Columbia Plateau, Washington. J Geophys Res 97(D3):2821-2833

van der Gun JAM (2010) Climate change and alluvial aquifers in arid regions: examples from Yemen. In: Ludwig F, Kabat P, Schaik H, Valk M (eds) Climate change adaptation in the water sector. Earthscan Publishing, London, pp 159-176

Van Dijck SJE, Laouina A, Carvalho AV et al (2006) Desertification in northern Morocco due to effects of climate change on groundwater recharge. In: Kepner WG, Rubio JL, Mouat DA, Pedrazzini F (eds) Desertification in the Mediterranean region: a security issue. Springer, Dordrecht, pp 549-577

van Roosmalen L, Christensen BSB, Sonnenborg TO (2007) Regional differences in climate change impacts on groundwater and stream discharge in Denmark. Vadose Zone J 6(3): 554-571

van Roosmalen L, Sonnenborg TO, Jensen KH (2009) Impact of climate and land use change on the hydrology of a large-scale agricultural catchment. Water Resour Res 45(7):W00A15

Vandenbohede A, Luyten K, Lebbe L (2008) Effects of global change on heterogeneous coastal aquifers: a case study in Belgium. J Coast Res 24(2 Suppl B):160-170

Wahr J, Swenson S, Velicogna I (2006) The accuracy of GRACE mass estimates. Geophys Res Lett 33:L06401. doi:10.1029/2005GL025305

Walvoord MA, Striegl RG (2007) Increased groundwater to stream discharge from permafrost thawing in the Yukon River basin: potential impacts on lateral export of carbon and nitrogen. Geophys Res Lett 34:L12402

Wang G (2005) Agricultural drought in a future climate: results from 15 global climate models participating in the IPCC 4th assessment. Climate Dynam 25(7):739-753

Wang T, Istanbulluoglu E, Lenters J, Scott D (2009) On the role of groundwater and soil texture in the regional water balance: an investigation of the Nebraska Sand Hills, USA. Water Resour Res 45(10):W10413 
Warner SD (2007) Climate change, sustainability, and ground water remediation: the connection. Ground Water Monit Rem 27(4):50-52

Waughray D (ed) (2011) Water security: the water-food-energy-climate nexus, World Economic Forum. Island Press, Washington, DC

White I, Falkland T, Metutera T, Metai E, Overmars M, Perez P, Dray A, Falkland AC (2007) Climatic and human influences on groundwater in low atolls. Vadose Zone J 6(3):581-590

Wilby RL, Harris I (2006) A framework for assessing uncertainties in climate change: low-flow scenarios for the River Thames, UK. Water Resour Res 42:W02419. doi:10.1029/ 2005WR00406

Wilby RL, Wigley TML (1997) Downscaling general circulation model output: a review of methods and limitations. Prog Phys Geogr 21:530-548

Windom HL, Moore WS, Niencheski LFH, Jahnke RA (2006) Submarine groundwater discharge: a large, previously unrecognized source of dissolved iron to the South Atlantic Ocean. Mar Chem 102:252-266

Winter TC (1983) The interaction of lakes with variably saturated porous media. Water Resour Res 19(5): 1203-1218

Winter TC (1999) Relation of streams, lakes, and wetlands to groundwater flow systems. Hydrogeol J 7(1):28-45

Woldeamlak ST, Batelaan O, De Smedt F (2007) Effects of climate change on the groundwater system in the Grote-Nete catchment, Belgium. Hydrogeol J 15(5):891-901

Xu C-Y (1999) From GCM's to river flow: a review of downscaling methods and hydrologic modelling approaches. Prog Phys Geogr 23(2):229-249

Yamamoto K, Hasegawa T, Fukuda Y, Nakaegawa T, Taniguchi M (2008) Improvement of JLG terrestrial water storage model using GRACE satellite gravity data. In: Taniguchi M, others (eds) From headwater to the ocean. CRC Press/Taylor and Francis Group, London, pp 369-374

Yang C, Chandler RE, Isham VS, Annoni C, Wheater HS (2005) Simulation and downscaling models for potential evaporation. J Hydrol 302(1-4):239-254

Yechieli Y, Shalev E, Wollman S, Kiro Y, Kafri U (2010) Response of the Mediterranean and Dead Sea coastal aquifers to sea level variations. Water Resour Res 46:W12550. doi:10.1029/ 2009WR008708

Yeh PJ-F, Swenson SC, Famiglietti JS, Rodell M (2006) Remote sensing of groundwater storage changes in Illinois using the Gravity Recovery and Climate Experiment (GRACE). Water Resour Res 42:W12203. doi:10.1029/2006WR005374

Yusoff I, Hiscock KM, Conway D (2002) Simulation of the impacts of climate change on groundwater resources in eastern England. In: Hiscock KM, Rivett MO, Davison RM (eds) Sustainable groundwater development. Geological Survey of London, London, pp 325-344

Zaitchik BF, Rodell M, Reichle RH (2008) Assimilation of GRACE terrestrial water storage data into a land surface model. J Hydrometeorol 9:535-548

Zektser IS, Loaiciga HA (1993) Groundwater fluxes in the global hydrologic cycle: past, present and future. J Hydrol 144(1-4):405-427

Zuppi GM, Sacchi E (2004) Hydrogeology as a climate recorder: Sahara-Sahel (North Africa) and the Po Plain (Northern Italy). Global Planet Chang 40(1-2):79-91 